\title{
HOTEL HOUSEKEEPING
}

OPERATIONAL

AUDIT

\author{
BY \\ DONALD F. WOOD \\ Bachelor of Business Administration \\ University of Mississippi \\ Oxford. Mississippi
}

1971

Submitted to the Faculty of the Graduate College of the Oklahoma State University in partial fulfillment of the requirements for the Degree of MASTER OF SCIENCE

August 2001 


\section{HOTEL HOUSEKEEPING}

\section{OPERATIONAL}

\section{AUDIT}

Thesis Approved:

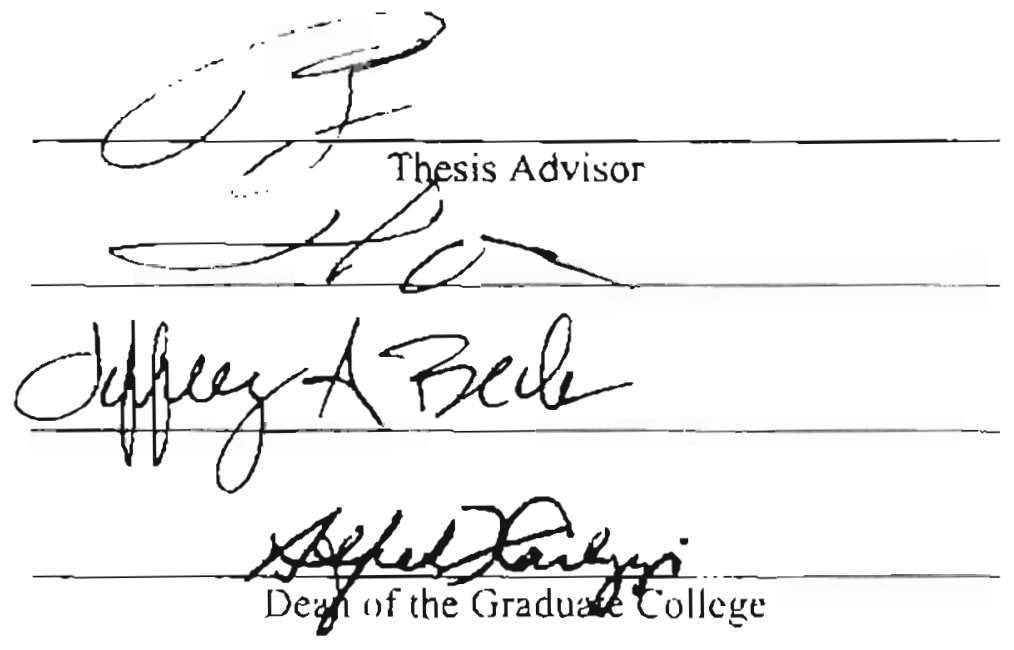




\section{ACKNOWLEDGMENTS}

I wish to offer my sincere gratitude and appreciation to my major adviser and thesis committee chair, Dr. Patrick J. Moreo. Dr. Moreo's interest, involvement, and encouragement motivated me to begin graduate school. His continued support. guidance, understanding, and friendship motivated me to complete this phase of my education.

I wish to gratefully acknowledge my other committee members. Dr. Jeff Beck and Dr. Hailin Qu for their invaluable insight and direction on this research and in many other areas. Special thanks go to Dr. Gail Sammons and Jade Tang, whom I was involved with on initial research that would be developed into this thesis.

I wish to express my sincere appreciation to Dr. Jerold Leong, Dr. Lynda Martin, Mr. Dick Autry, and Paul Sorrentino for making me fecl like an important part, not just a student, of this great School of Hotel and Restaurant Administration. Spccial thanks to my Word guru. Gloria Baum. Clieryl La Fave, and Kelly Way, tor their help and friendship. I also thank Rosalie Moreo for her hospitality, suppor, and friendship.

I wish to thank my colleague, Dr. Cihan Cobanaglu, for all of his invaluable help and friendship from he and his wife Gunay.

The love, support, and encouragement of my sister, Margarct E. Wood-Freeman, and my brother in law. Dr. Kenneth P. Freeman helped immensely in making this a reality. 
This thesis is dedicated to my father. John T. Wood (1914-2000) and my mother.

June K. Wood whose unconditional love, support, and encouragement is immeasurable. 1 wish to express my sincere gratitude to all of my family. 


\section{TABLE OF CONTENTS}

Chapter

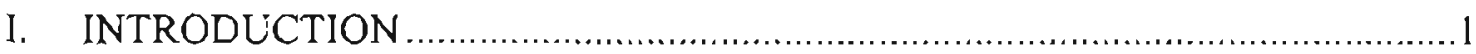

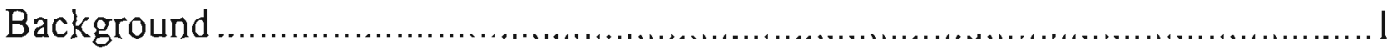

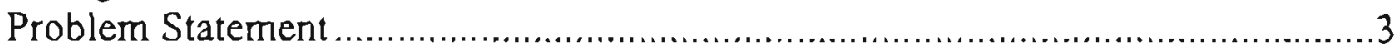

Purpose of the Study ..........................................................................

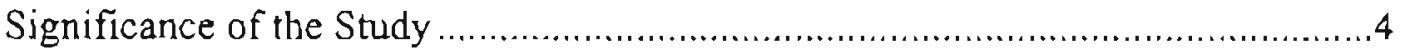

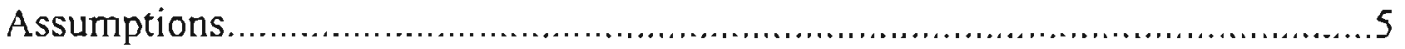

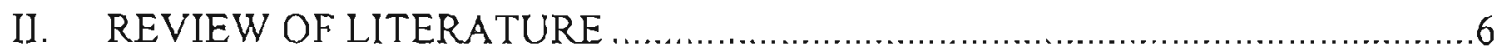

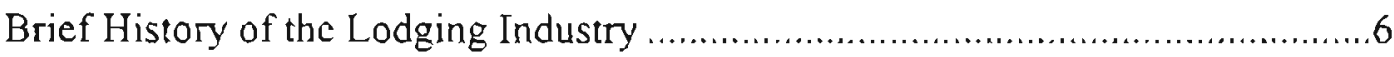

Hotel Housekeeping Management Structure ................................................. 7

Hotel Interdepartmental Communication ................................................. 12

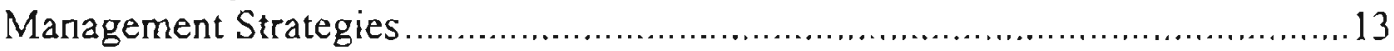

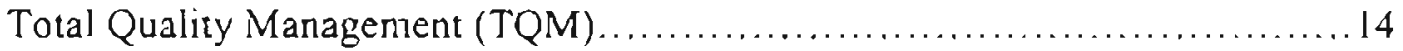

Operational Auditing in Hospitality Management........................................... 16

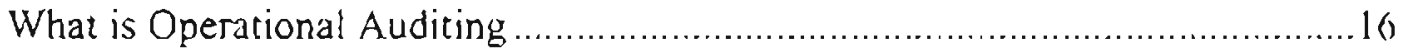

Functions of the Operational Audit.................................................. 18

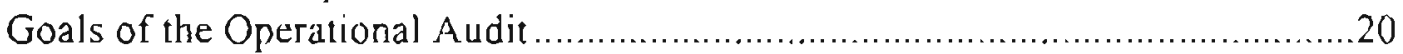

Format and Implementation of the Operational Audit.................................... 1

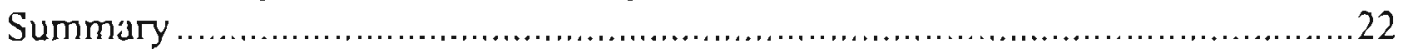

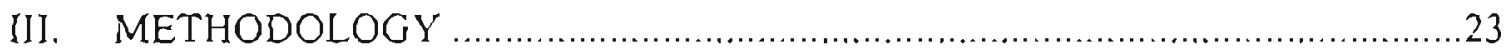

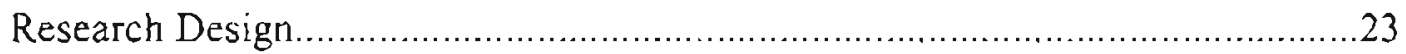

Data Collection Procedures................................................................... 24

Data Analysis Design ......................................................................26

Categories and Codes for Housekeeping Operational Auditing ........................29

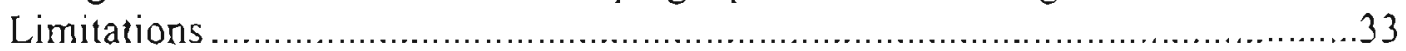

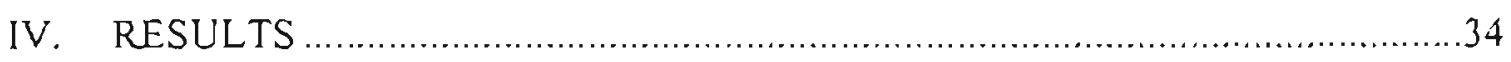

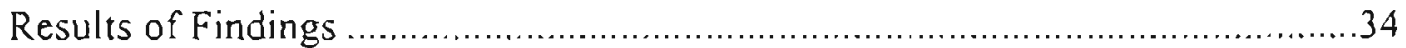

Summary: Descriptive Statistics of Major Categories ..................................36

Descriptive Statistics of Categories and Sub-Categorıes..............................40

Hotel Housekeeping Operational Auditing Qucstionnaire ............................42 
V. SUMMARY, CONCLUSIONS, AND RECOMMENDATIONS ..............61

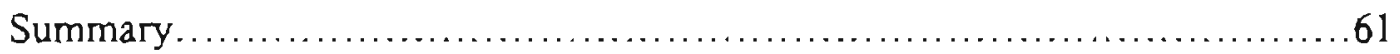

Summary of Findings and Conclusions ..................................62

Recommendations and Future Research .................................64

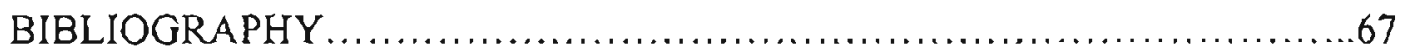

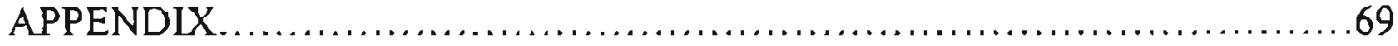

APPENDIX A Institutional Review Board Approval ........................69 


\section{LIST OF TABLES}

Table

I. Categories and Codes for Hotel Housekeeping Operational Audit .29

II. Summary: Descriptive Statistics of Major Categories .............................. 36

IIl. Descriptive Statistics of Coded Categories and Sub-Categories .....................40

\section{LIST OF EXHIBITS}

Exhibit

Jage

1.1 Sample Organization Chart for Midsize Rooms-Only Hotel..........................

1.2 Sample Organization Chart for a Large Hotel ................................... 0

1.3 Housekeeping Department Organization, ............................................. I

2.1 Complete Hotel Housekeeping Operational Audit ...................................42 


\title{
CHAPTER I
}

\section{INTRODUCTION}

\author{
Background
}

Hotel classifications cover the spectrum from economy or budget properties offering little or no amenities to luxury full service operations which include any type of convenience expected by hotel guests in any country in the world (Casado, 2000). Within these two parameters niche marketing by hotel companies has created a specific hotel brand to accommodate a wide variety of travelers' preferences. Regardless of the classification or size of the hotel, cleaning guest rooms and those areas accessible to the public are common characteristics of needs to all lodging properties.

The management structure in a large hotel may have a staff that reports to an executive housekeeper who reports to a Director of Rooms who then reports to the General Manager. Conversely, in a small limited service property the housckeeping staff could repon directly to the General Manager. In any hotel opcration the final impact of the housekeeeping department is that if the cleaning of the rooms and public space is not properly done guest satisfaction could diminish and adversely effect occupancy and revenue (lverson, 1989).

Casado (2000) proposes that there are three levels of management expertise needed to successfully manage a hotel housekeeping department: management of resources. administration of assets, and technical knowledge of housekeeping operations. 
To accomplish these tasks Henri Fayol's management principles of planning, organizing, directing, coordinating, and controlling can apply directly to hotel housekeeping deparments (Casado, 2000).

In a fast paced, growing, and highly competitive economic environment managers look for tools to help implement these principles in their operation to produce economic, efficient, and effective results. Operational auditing is a tool that can be used to ensure that management practices are being conducted properly and are guiding the organization tow'ard its intended goal (Reider, 1994).

The term operational auditing started to get considerable attention in the late 1960's when the United States General Accounting Office (GAO) started developing operating auditing procedures for the federal government. Concise guidelines for operational auditing focusing on economy, efficiency, and effectiveness were published in 1972 and have been performed by astute managers since (Driessen \& Mollenkainp, 1993). There have been many commonly recognized definitions of operational auditing but not one that has been universally accepted. Driessen \& Mellenkamp (1993) define the operational audit as an independent, internal review of an organizational unit or a process in which an opinion can be rendered systematically to business management. Flesher and Siewart (1982), assert that an operational audit is an organized search for ways of improving efficiency and effectiveness. Although operational auditing has been defined in various ways, the following concise definition by Moreo and Savage will be used in this research: "The operational audit is an organized review of a deparment 's operating procedures" (Moreo and Savage, 1990, p. 243). 
Additionally, hotel housekeeping operational audits could be very imporant to all levels involved in the department including management, supervisory, and front line employees. The operational audit would allow all these individuals to gain more control over the management functions for which they are responsible for (Moreo, Sammons, and Savage, 1997).

\section{Problem Statement}

Although it is widely known that hotel companies have conducted operational audits, the proprietary nature of these audits prevents full accessibility to them. The practice of operational auditing in the hotel industry could be improved by documenting current practices, identifying areas of relative importance and potential deficiencies then integrating this information into a complete operational audit format specifically for hotel housekeeping departments (Morco and Sammons, 1997).

Several studies have been performed to develop an operational audit system for the hotel front office department (Moreo and Sammons, 1990, 1997). There has not been a study that has developed a generic hotel housekeeping operational audit process that can be customized for individual hotel properties, corporately owned single brand chains, or multi-branded operations. 
Purpose of the Study

The purpose of this study is to identify important audit and checklist procedures of selected hotel housekeeping operations in North America and develop a generic, customizable operational audit specific to this segment of the hotel industry.

\section{Significance of the Study}

Several studies indicate that an operational audit is important at all levels of operations from management to front line employees. In the past several years terms such as "Employee Empowerment," "TQM," and "Systems Design" have become so popular in the hospitality industry that they have been implemented in many operations. This audit could be an extremely valuable sool for measurement and follow up of these concepts. A generic self- administered housekeeping operational audit would provide information for hotels to incorporate in their training programs to ensure quality service.

Additionally, the audit could be used to delineate areas of strengths and weaknesses in operations and be a managenient tool for employee motivation, reward, and developmental guidance. Economically, the use of an operational audit could reduce extemal audit costs. Operational audit results have been found to be more valuable in cost reductions than financial audits in many operations (Spraakman and Ibrahim, 1998).

A generic housekeeping audit could also efficiently augment a hotel's management procedure and technique by utilizing depanmental employees to perform the audit. 


\begin{abstract}
Assumptions
It is assumed in this study that the targeted hotels utilize some form of operational auditing procedures and/or checklists, either formally or informally. Also it is assumed that hotel housekeeping operations in all selected hotels have some common characteristics.
\end{abstract}




\section{CHAPTER II}

\section{REVIEW OF LITERATURE}

\section{Brief History of the Lodging Industry}

The term hotel is derived from the French word hostel, or in modem lexicon, hotel, and suggests an establishment offering accommodations and amenities for travelers with up-to-date accoutrements (Cassado, 2000). The first United States inn, built in Gaiford Connecticut in 1640, broadly fits this description (Schneider, Tucker, and Scoviak, 1999). In New York City, The City Hotel, the first building that was designed specifically for hotel operations opened in 1794. After this beginning the lodging industry flourished in the United States until the Great Depression in 1930 that caused the demise of eighty-five percent of operating hotels (Lattin, 1989).

The years after World War II were marked by intense development within the hotel industry, In the prosperous post-war era the needs of travelers were met by growing hotel companies such as Mariott, Sheraton, and Hilton Hote's. In the 1950's motels such as Kemmons Wilson's Holiday Inns began to gain widespread popularity. These motels offered basic services at a lower cost and were constructed on roads convenient to or en route to family attractions (Cassado, 2000).

In the 1960's and 1970's increased personal disposable income and expanding businesses pushed the demand for airline use higher for more distant vacation travel to developing resort areas and business destinations. 
It was at this point that market segmentation started to become very imponant to the hotel industry in developing and managing lodging properies to meet diverse demand. It became imperative for all operating departments, including housekeeping, to develop strategies for managing hotels in these different market segments (Schneider, Tucker, and Scovjak, 1999).

The reason for hotel housekeeping departments' need for different strategies for separate hotel classifications is primarily in the level of service offered to guests in each segment. As an example, a housekeeper in a luxury property has more square footage, more amenities to be monitored and usually requires more than one visit per day in comparison to hotels offering basic services. However the need for housekeeping services is still critical regardless of size or classification. (Cassado, 2000).

\section{Hotel Housekeeping Management Structure}

The general manager of a property is responsible for coordinating and directing all divisions or departments of a hotel to carry out the mission and objectives of the company. Examples of management organization charts are shown in exhibit 1.1 and 1.2 (Kappa, Nitschke, and Shappert, 1990). The departments could include rooms division, food and beverage, sales and marketing, accounting, engineering and nlaintenance, security, and human resources.

The deparment heads usually form the executive committee of a hotel property. In full service hotels the executive housekeeper is on the committce reporing to the resident 
or rooms division manager. A typical hotel housekeeping department organization chart is shown in exhibit 1.3. 


\section{Exhibit 1.1 Sample Organization Chart for a Midsize Rooms-Only Hotel}

(Kappa, Nitschke, and Shappert. 1990)

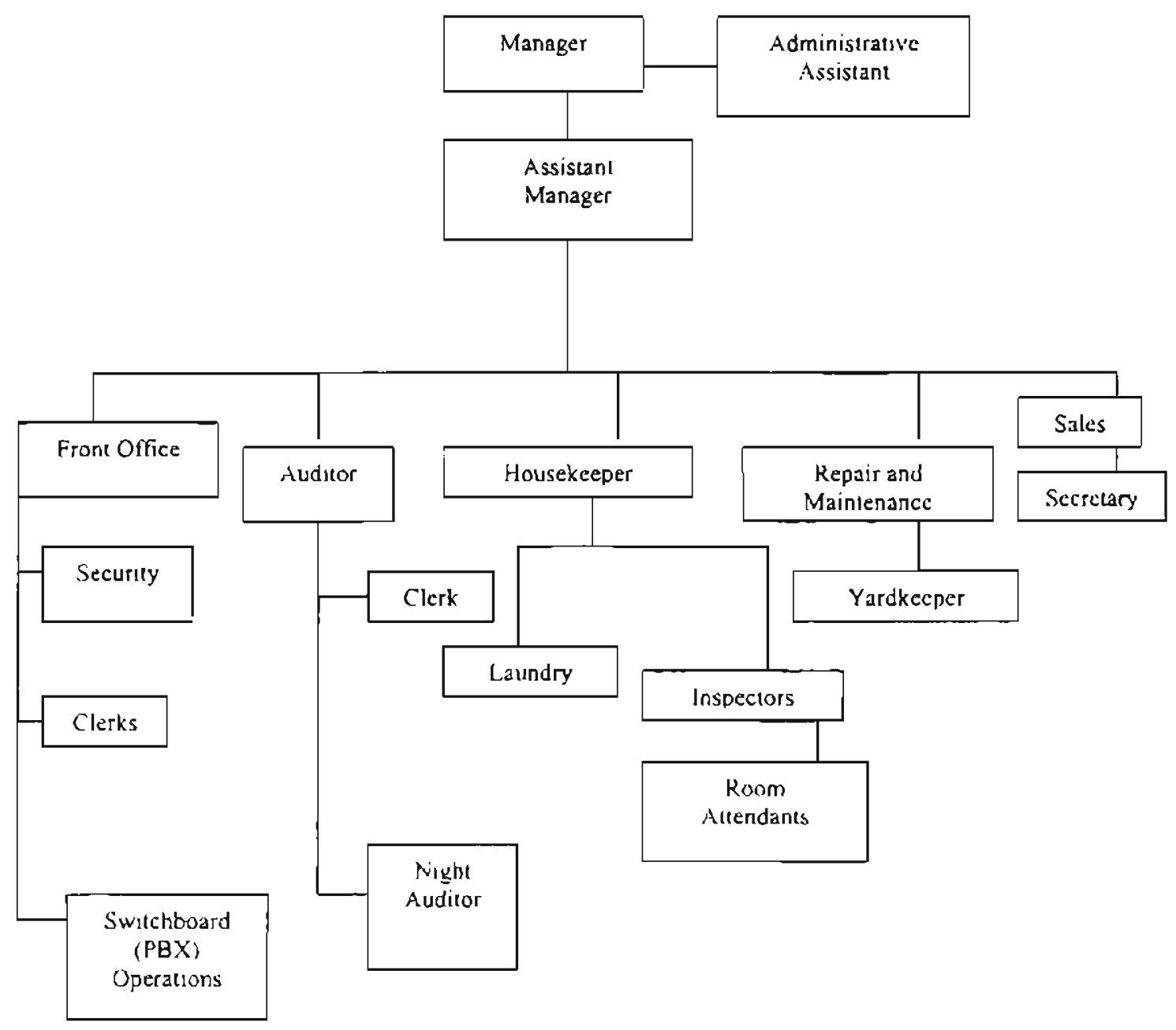




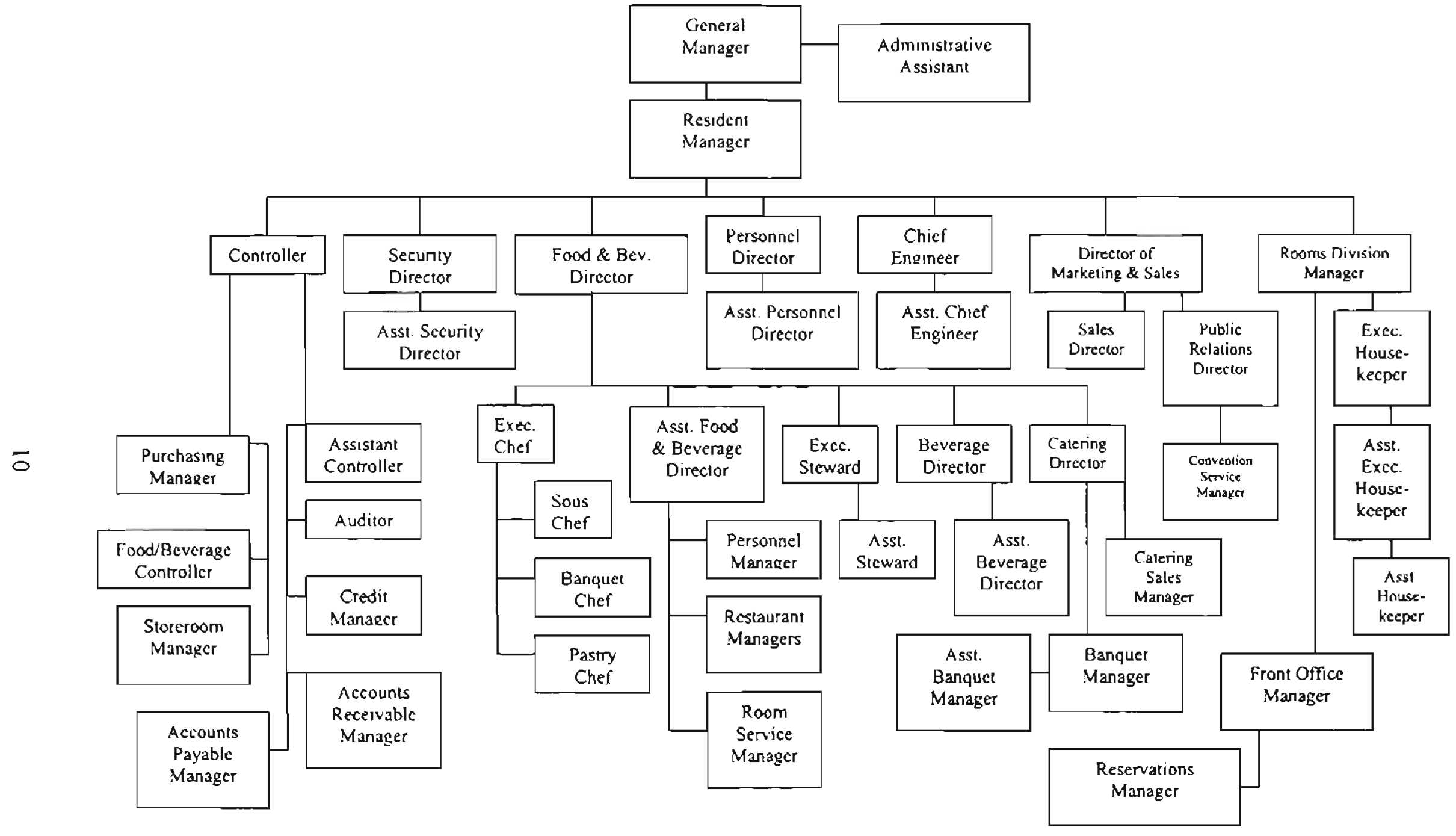

Exhibit 1.2 Sample Organization Chan for a Large Hotel (Kappa, Nitscbke, and Sbappert, 1990) 


\section{EXHIBIT 1.3 HOUSEKEEPING DEPARTMENT \\ ORGANIZATION}

(Kappa, Nitschke, and Shappert, 1990)

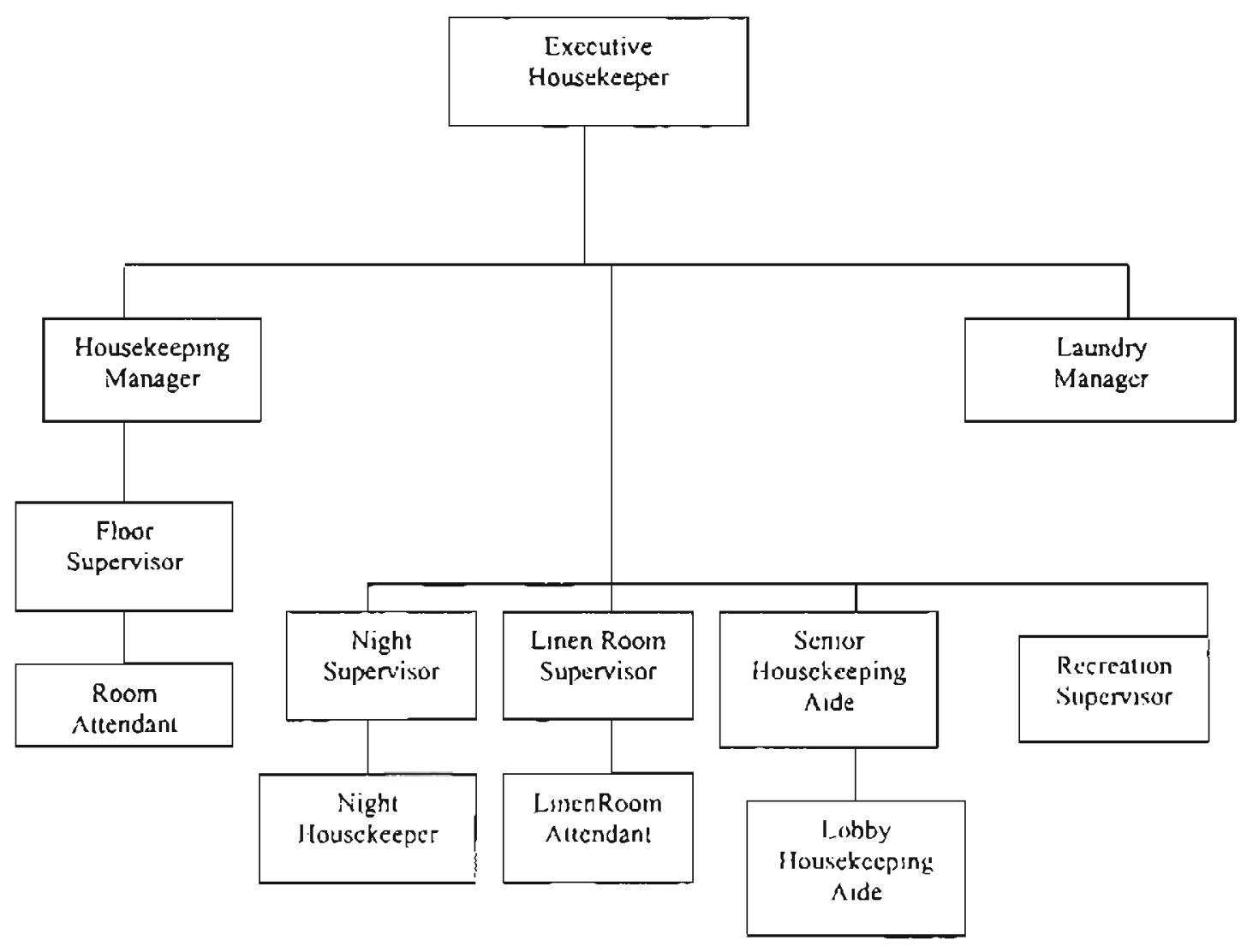




\section{Hotel Interdepartmental Conmunication}

Regardless of size, classification, or company structure of a hotel, the guestrooms and the public area must be cleaned and maintained properly. Martin (1998) states that effective management of the hotel housekeeping department is crucial to success of the property. The department is an integral element in the operation of a property and must interact with all other departments. Primarily, that means direct communication with front office and engineering. Beyond its primary responsibility of cleaning guest rooms and public space the housekeeping department must have a strong relationship with food and beverage, sales and marketing, security, and human resources (Martin, 1998).

The operations of housekeeping departments require communication with other departments within the hotel on a daily basis. According to Reider (2000) a properly executed operational audit could measure the effectiveness of communication between deparments. The results of an audit could alert management 10 problems evolving from different interpretations of information given to other departments by housekeeping and vice versa.

The communication loop begins with the rooms division, which forecasts occupancy as well as issues actual figures to the housekeeping department. Housekeeping should then staff accordingly and issue room status reports on a very timely basis to avoid guest check-in delays. Engineering and maintenance must be constantly aware that all turnishings and equipment are in proper working order and good repair in both guestroom and public space areas. In addition, the housekeeping deparment is usually involved with engineering in identifying and tracking preventative maintenance needs. 
Housekeeping is labor intensive and requires good communication with human resources to keep its department properly staffed. In most medium to large properties human resources is the department responsible for screening, documenting residency, and obtaining employee tax and personal information necessary for employment. Due to leadtime for a new hire, their accual start time in the department. and turnover factors in housekeeping this is an essential relationship (Casado, 2000).

Communication with the food and beverage department is important not only as it relates to guests' room service orders, but also to the housekeeping laundry operation that supplies linen to the restaurant and catering departments.

It is also important for housekeeping to work closely with the sales and marketing, and accounting departments. The housekeeping depanment has the responsibility to deliver what the sales and marketing people sell. The rooms have to be clean and available to guests as quoted by the sales department. The relationship with accounting serves two main purposes. One is placing orders for equipment and supplies and, two, performing the payroil function for employees. All employee wages, increases, bonuses, and hours worked must be reported in order to calculate labor costs for the department. In addition, purchases of supplies. fumiture, fixtures and equipment should be compared to budgetary parameters (Casado, 2000).

\section{Management Strategies}

In 1916 Henri Fayol proposed that a manager must follow five functions of management, planning, organizing, coordinating, and controlling. He also stated that they 
could be applied to any type of business and various levels within. Therefore, it can be applied to the hotel industry and to the housekeeping department specifically (Casado. 2000). Overall these functions can be carried out in two different approaches, centralized or decentralized.

Currently in the United States a decentralized form of management is the irend. The reason for this is predominantly due to cutting labor and focusing on cost control. One of the goals of this management approach is to make employees more responsible and responsive in carrying out their job responsibilities (Schneider, Tucker, and Scoviak, 1999).

In conjunction with utilizing classical forms of management, the hotel industry has augmented its techniques with a more participative approach to empower employees to make decisions, handle problems and ensure guests satisfaction (Schneider. Tucker. and Scoviak, 1999). The concept of empowerment allows employees to carry out the principles of "Total Quality Management" (TQM) by giving them greater decision making leeway to accomplish guest satisfaction. The (TQM) elements that apply to hotel housekeeping operations focus on continuous improvement in the quest for quality, what the guests require, and whether or not it is actually being delivered (Casado, 2000).

Total Quality Management (TQM)

The term, total quality management was first coined by the United States Naval Air Systems Command. They used the term in describing their management approach to quality improvements (Bhote, 1991). In the 1930's Walter Shewhart of Bell Laboratories 
used probability mathematics in developing statistical analysis for quality control. Dr. W. Edwards Deming used those methods to develop his quality management concept that he introduced to Japan in the 1950's. Armand Feigenbaum, Dr. Deming, Dr. Joseph Juran, and Phillip Crosby are all credited with influencing the Japanese approach to toward quality management. However. Dr. Deming is considered by many to be the chief architect of TQM. (Gabor, 1990). Deming's major developments were "The Deming Cycle," "Deming's Fourteen Points," and "Deming's Seven Deadly Diseases." The Deming cycle links production of a product or rendering of services with the needs (Goetsch and Davis, 2000). The components of the Deming cycle consist of plan, do, check, act, and analyze. The steps consist of consumer research, making the product or delivering the service, checking the processes, marketing, and finally, analyzing the results of market acceptance in terms of quality and cost. Dr. Deming stated that at least $85 \%$ of a company's failure is related to management and that employees accounted for less than $15 \%$. He also states that over $90 \%$ of those problems can be attributed to poorly planned and executed processes. In addition, management should focus on continuous improvement to overcome these problems (Deming, 1986).

Reider (1994, 1999), Moreo, Sammons, and Savage (1990) suggest that an operational audit could enhance total quality management and the continuous improvement process in several ways. A hotel bousekeepıng operational audit involves management and employees working together in a fact- finding process, not a blame statement exercise. Employees are encouraged to participate in the ongoing development of the audit process which could be an empowerment benefit to them. Finally the operational audit focuses on actions that could directly impact guest satisfaction. 


\section{Operational Auditing in Hospitality Management}

It is difficult to determine exactly when operational auditing first started. Some form of it was documented as early as 1875 by the Krupp Company in Germany to determine if their business was being conducted according to established policies and procedures. According to company records the auditors were to make criticisms with recommendations for improvement (Flesher, and Siewart, 1982).

The term operational auditing gained attention in the United States in the late 1960's when the U.S. General Accounting Office (GAO) developed operational auditing procedures for the federal government. In 1972 the Standards for Audit of Govemment organizations. Programs, Activities, and Functions (also known as the "Yellow Book") was published.

These guidelines emphasize economy, efficiency, and effectiveness (Godick. 1979). The GAO guidelines and procedures prompted the American Institute of Certified Public Accountants (AICPA) to get more involved in operational auditing and published "Guidelines for CPA Participation in Govemment Audit Engagements to Evaluate Economy, Efficiency, and Program Results" (New York: AICPA, 1977)

\section{What is Operational Auditing?}

The term operational auditing has been widely used. but there is no universally accepted definition. Meddaugh (1979) suggests that operational auditing can be described 
in terms of either conceptual levels or functional activities. The conceptual levels include business, procedures, performance, and management auditing. The functional levels include activities within specific operating departments of the business.

Flesher and Siewart (1982) assert that an operational audit is an organized search for ways of improving efficiency and effectiveness. Ponder (1984) states that an operational audit serves as a tool which reviews and documents how operations of a particular company or department are being managed. Kolwalczyk (1987) states that the term operational auditing changes as the years change and it is a methodology equated with internal auditing.

Driesson and Mollenkamp (1993) contend that operational auditing and intemal auditing are two separate concepts. The internal auditor focuses on the reliability of financial information, but the operational audit focuses on activities/procedures being performed. They define the operational audit as an independent, internal review of an organizational unit or a process in which an opinion cans be rendered systematically to the business's management.

Although operational auditing has been defined in various ways the simple, concise definition proposed by Moreo and Savage is used in this research: "The operational audit is an organized review of a department's operating procedures" (Moreo and Savage, 1990, p.243). 


\section{Functions of the Operational Audit}

An operational audit functions as a management tool to augment the process of running a business as or a deparment of a business as effectively, efficiently, and economically as possible. The auditing process is particularly beneficial, operationally, when trying to identify areas that need improvement, isolating the cause of a problem, determining the effect of current procedures. and developing a course of action to correct weaknesses (Reider, 1999). Both management and staff could benefit from an operational audit. According to Reider (1994), depending on the scope of the audit engagement, some or all of the following areas under a review process could yield positive results:

1) Identifying weaknesses, their causes, and alternatives for improvement.

2) Isolating areas that contribute to waste and inefficiency that could be eliminated without loosing efficiency and effectiveness.

3) Finding areas for income enhancement.

4) Locating organizational goals, policies, procedures, and objectives that are not clearly stated or the structure could be improved.

5) Assessing the parameters of measuring the success of adhering to or accomplishment of these policies, procedures, goals, and objectives.

6) Auditing for legal compliance of policies and procedures.

7) Performancc checks on progress by individuals or business units meeting objectives.

8) Uncovering fraudulent, unauthorized, or inegular activities.

9) Enhancing communication between management and employees. 
10) Producing an independent, objective assessment of operations.

The uses and benefits of operational auditing have not been confined to one particular industry. However, most research in the field has been directed toward manufacturing versus service industries (Corcell, 1983). In recenc year's studies of operational auditing in the hospitality sector, specifically hotels, have been developed. Mace and Valentine (1984) state that operational auditing could be an important element of the strategic planning process because of its future orientation, design to identify problem areas, and recommendation of alternatives.

According to Moreo and Savage (1990), operational audits are being performed by hotels, but the knowledge of the actual procedures being used is limited due to their proprietary nature. Additionally, Moreo, Sammons, and Savage (1997) state that the use of operational auditing in hotels could be improved by documenting current practice, identifying areas of deficiencies, and combining the information into a comprehensive audit specific to the hotel industry. Hotels that currently utilize some form of opcrational audits. as well as properties that do not, could benefit from the procedure. Hotels that do use some type of audit or checklist would have a comprehensive model available to them for comparison to current best practices in the industry as a whole to their own procedures. This comparison would highlight incomplete, missing, or areas that could be added to their current audit. Hotels not currently performing operational audits would have a prototype to use in developing and implementing their own procedures (Moreo and Savage. 1990). 


\section{Goals of the Operational Audit}

A comprehensive, generic hotel housekeepıng operational audit could help accomplish several goals for property management. According to Moreo, Sammons, and Savage (1997) one of the most important aspects of an audit is that it be usable for all hotel properties. Chain hotels are usually subject to audits by the franchise or corporate office inspection teams assessing the adherence to company standards. Adhering to standards of service, quality, and cleanliness are important, but it is usually based on system-wide parameters. Consequently, a property in one geographic location is being assessed by the same criterion as a property in a totally different geographic and possibly demographic location. The inspection for the standards then becomes the inspection for sameness; "When companies try to have sameness without regard for the local environment and needs, the result is mediocrity." (Moreo. Sammons, and Savage, 1997. p. 17).

"Systems design" is a term that is frequently used in hospitality management. An operational audit could be critical to the design and implementation of these system procedures, particularly in the feedback and evaluation phase. An audit could provide a built in assurance that the crucial step of evaluation would occur before the system was altered (Moreo, Sammons, and Savage, 1997). 


\section{Format and Implementation of Operational Auditing}

Operational audits vary with the industry utilizing them and with indiviơual firms within those indusmies. Checklists or questionnaires are often used for auditing procedures. Corcell, (1984) states that a well designed questionnaire should motivate people to develop ideas and stimulate their creativity. Moreo, Sammons, and Savage, (1997) developed an audit questionnaire for hotel front office operations which is selfadministered and designed to be implemented by most, if not all of the front office employees. The questionnaire allows for yes, no, not applicable answers as weil as space for comments to each question. A copy of the questionnaire is provided to all department personnel with their applicable duties highlighted in each section. The staff, supervisors, and management then review the items, adding, deleting, and modifying when needed.

After the audit questionnaire has been reviewed and modified, a comprehensive explanation of the purpose, process, and. scope is presented to all those who will be involved in the process. Following this, each person, by shift, in all areas complete the questionnaire and review the results for identifying present needs and futurc usc (Morco. Sammons, and Savage, 1997). It is at this point that Deming's cycle of plan, do, check, act, and analyze as described in the previous TQM section could be implemented. 


\section{Summary}

There have been dramatic changes in the hotel industry in the United States since its beginning in the late 1600's. The scope of the changes is evident in the physical structures as well as management structures and strategies currently in existence. Hotel management structures and strategies have been developed for a vast array of different market segments, locations, levels of service, and pricing. Throughout the many years of change there appears to be one constant, rooms and public space of hotels have to be cleaned. Operational auditing could be a viable tool in helping to accomplish that task with quality.

Operational auditing has also been refined and developed during this span of time and has been proven to be applicable to the hotel industry. There are many compelling reasons which could lead to concluding that a operational audit could be important to all levels of employees, including management, supervisors, and staff. The most important reasons identified are quality assurance for guest satisfaction and the operational information that an audit could yield. 
CHAPTER III

\section{METHODOLOGY}

\section{Research Design}

The objective of this study was to research operational pattems and practices of hotel housekeeping departments in order to develop a generic housekeeping audit specific to the industry. The research design utilized was qualitative and incorporated several elements of inquiry such as content analysis of documents, fleldwork with participant observation, and interviewing. "Content analysis is a quantitatively oriented technique by which standardized measurements are applied to metrically detined units and these are used to characterize and compare documents" (Berelson, 1952; Kracauer, 1993). The two main advantages of content analysis are that it is unobtrusive and easily replicated. This methodology can be applied to information for the purposes of identifying inportant characteristics of the material (Ary, Jacobs, and Razavieh 1996).

Qualitative research differs from quantitative in that the latter is composed of a concise presentation of methods and results of the study whereas qualitative design must provide a persuasive reason that systematically supports the researcher's case.

Additionally, there are four main methods of ensuring strictness in qualitative studies that were employed in this research. The major methods were criteria of adequacy and appropriateness of data, the audit trail, verification of the study with secondary informants, and using multiple raters. Adequacy refers to the amount of data collected for 
a qualitative study versus the number of subjects for a quantitative research design. Appropriateness refers to the method of sampling that meets the needs of qualitative research. which is purposeful rather than a form of random sampling. "These four main methods are intricately connected to validity and reliability" (Morse 1986).

This research paradigm appeared appropriate for the objectives of this study and the data structure and sources available. It was first necessary to organize the approaches which hotels took to housekeeping management operations and to identify the most prevalent techniques used. This research attempts to identify the questions to be asked in constructing a useful housekeeping audit.

The resulting data analysis yields frequencies of practices and patterns of operational techniques employed by 25 hotel companies in the United States. Since the narre of the research design does not warrant the application of sophisticated statistical analysis, descriptive statistics reporting the fiequencies, means, and ranges of each coded category and a qualitative summary of the contents of the checklists was presented.

\section{Data Collection Proccdures}

The basis for this study was a set of 25 housekeeping operations manuals obtained from large hotel, motel, and casino companies in the United States. Sixty diverse lodging companies were selected from The American Hotel and Motel Association's Directory of Hotel and Motel Companies to be contacted. The process of selecting the sample hotel companies was reviewed apriori hy a panel of hotel management experts that looked for the most representative of top tier hotel companies in the industry. A proportional 
stratified convenience sample of ten hotel companies in each classification of budget, limited service, mid-range, full service, luxury, casino/hotel properties was selected. "When the population consists of a number of sub-groups or strata, that may differ in the characteristics being studied, it is often desirable to use a form of probability sampling called stratified sampling" (Ary, Jacobs, and Razavieh 1996). In addition to the classification criterion, only multi-property companies were chosen. It was the intent of the researchers to include a broad spectrum of operations which would be representative of the diversity of hotel companies in the United States.

The Directory of Hotel and Motel Companies included a list of the top 50 branded hotel companies in the world ranked by total properties and total rooms. Within the 50 companies were their listings of multi-property hotel divisions, i.e. Marriott International, Ritz-Carlton, Courtyard by Marriott, Renaissance Hotels and Resorts, Fairfield Inns, Residence Inns, Ramada, et. al. The list was divided into categories of branded hotel companies by domestic and non-domestic hotels. For the purposes of this study only companies in the domestic category were used as a basis of selecting the sample. Ten companies per classification were selected from the top tiers of the ranked companies. The 60 hotel companies selected represented over 13,400 (60.1\%) propertics with $1.800,000+$ rooms out of more than 22,000 in the top fifty list. The reporting hotel companies represented over $8,400(62.7 \%)$ hotels with over $1,000,000(55.6 \%)$ rooms of the selected sample.

Letters were mailed to the companies requesting housekeeping operations manuals, audits. or checklists. A follow-up letter was sent to non-respondents 3 weeks after the 
initial request. A third follow-up was made by telephone two weeks after the follow-up letter was mailed.

Fourteen hotel companies sent operations manuals or audit checklists. Additionally, 11 manuals were obtained through personal contacts with industry executives who, after reviewing the purpose of the study, provided all material relevant to the research that was utilized by their company.

The categories of hotels providing the information represent budget, limited service, mid-range, full service, luxury, and casino/hotel properties. The classification breakdown of reporting hotels consisted of 6 casino/hotels, 6 full service, 5 limited service, 3 luxury, 3 mid-range, and 2 budget hotels. Additionally, the company structures were 2 independent, 3 hotel management companies, and twenty corporately owned properties. However, the sample population was not randomly selected and therefore no inference from the data can be made beyond the responding companies. Data collected were further evaluated and refined based on a pilot test done to field test for usefulness of the operational audit questionnaire and is further explained below.

\section{Data Analysis Design}

A content analysis of hotel housekeeping operational audit procedures and checklists provided by the 25 hotels was performed to document current practices. A team consisting of researchers who were all former hotel managers, housekeeping managers, and hotel consultants was assembled to analyze the manuals, audits, and check lists which the team received. The team first analyzed the material to divide it into 
operationally segmented categories. In addition to their managerial expertise in delineating the categories, the team relied upon operational areas of hotel housekeeping management as set forth in The Professional Housekeeper (Schneider, Tucker, and Scoviack, 1999). This textbook was chosen for its clarity, completeness and use by many hotel and restaurant schools in the United States. After establishing operational categories the researcher and other team members assigned a "code" to each incident in every document received from the respective hotel companies.

The sections of the manuals and checklists were divided into 80 categories and subcategories and analyzed for the relative total emphasis which the companies, in aggregate, placed on each of the operational areas. Each of the 80 categories was coded and analyzed for the number of incidents reported by each hotel. The operational audit was further developed by using the researchers' own experience in the industry to add, delete, and modify the questionnaire in areas that were missing, incomplete or valgue.

The questionnaire was then field tested in three hotels of different sizes, geographical locations, and classifications. The researcher worked with each hotcl housckecping employee during all shifts in the department interviewing employees, supervisors, and managers who used the audit questionnaire. The field testing of the audit questionnaire was done in a 500 hundred room Mobil four-star luxury hotel, a 300 room full service casino/hotel, and a 175 room limited service property. The field test procedure in the luxury and casino/hotel were similar because each hotel had fully staffed and separate departments. The limited service hotel housekeeping deparment handled all of the operating functions in the questionnaire except for maintenance. 
The questionnaire was divided into three main parts, management, supervisory, and employees. The categories of human resources, training, organization of department, inhouse laundry, communications, expenses, and purchasing were reviewed with management. The categories of guestroom cleaning, public area cleaning, inventory, and maintenance were reviewed with supervisors and employees. There were minor variations of who was assigned to review the questionnaire with the researcher due to different organizational structures and availability of personnel during the field test. Almost all of the comments from management and employees regarding the questionnaire selated to the language used in the questions themselves. Their suggestions related to clanty and the ability of the staff to understand the questions being asked. The feedback from this process enabled the researcher to obtain comments and recommendations for changes to the questionnaire. Based upon the responses from the field, changes to the audit questionnaire wore made.

Results of the field test provided sufficient information to enhance operational functions of the depanment as well as the content and implementation of the audit. In addition it reinforced the idea that line employees should be an integral part of the operational audit process. The complete generic operational audit questionnaire is presented in Exhibit 2.1 in chapter IV. 


\section{Data Coding}

Each section of the hotel housekeeping operations manual was treated as a separate category with sub-categories within each section for the purpose of coding. A set of codes was developed for each category and sub-category to reflect all major subject areas contained in the manuals or checklists. Abbreviations and definitions for the codes used to analyze the data are contained in Table I.

TABLE I

Categories and Codes for Hotel Housekeeping Operational Audit

CL I Clearing: Guestrooms

l Living area

b Bathroom

m Mattress and bed

g General

e Entry

CL 2 Cleaning: Public space

c Corridors, stairs, vending, elevator

l Lobby

g General

b Back of house

r Restrooms

e Exterior

- Outlets

E Expenses

I Cost control

2 Budgeting 
3 Quality management

4 Inspections

5 Age and condition of inventory

GS Guest Services

L Laundry

1 Linen rotation

2 Chemicals

3 Guest

4 In-house laundry

5 General

S Safety/Security

1 HAZCOM/MSDS/blood bome pathogens

2 Room/security/safety

3 General

PM Preventive Maintenance

1 (HVAC) Heating, ventilation, and cooling

2 Safety

3 Bathroom

4 Living area

5 Building: interior

6 Building: exterior

TR Training

1 Safety

2 ADA

3 CPR

P Purchasing

1 Linen

2 Guest room supplies

3 Amenities

4 Carpet

5 Furniture

6 TV

7 Drapes

8 Equipment

HR Human Resources

1 Orientation

2 Scheduling 
3 Hiring procedures

4 Appearance

5 Employee relations

CO Communication

1 Rooms control: housekeeping

2 Between departments

3 Work orders

4 Follow-up

5 Guests

6 Employees

O Organization of Department

1 Teams

2 Scheduling of sections

3 Organization chart

4 Carts

5 Storage

6 Operations

There were 1527 questions or statements from the hotel housekeeping manuals, checklists. and audits that were coded by category. The following are some examples of those statements and questions that comprise the "category" section of Table I:

\section{CL1: CLEANING ROOMS}

- Room is odor free

- Private bar restocked and cleaned daily

- Are employees instructed to keep all linen off the floor when miking beds or cleaning rooms?

- Procedures for clcaning the bathroom

- How to make a bed

- Restock all bathroom linen according to par

\section{CL2: CLEANING PUBLIC AREAS}

- Clean guest elevarors, doors, and tracks

- Vacuum the hall

- Arrange hall fumiture anú vacuum fabric

- Check hallways and ashtrays in guest lobby area

- Clean all corridor light fixtures and replace bulbs as needed

- Shampoo lobby carpet according to scheóule 


\section{E: EXPENSES}

- Are staffing guides used for scheduling?

- Calculation of man hours per occupied room

G: GUEST SERVICES

- Lost and found articles must be turned in to security

- The following are VIP guest procedures

\section{L: LAUNDRY}

- Linen rotation procedurc

- Proper handling of cleaning supplies

\section{S: SAFETY/SECURITY}

- List of safety cquipment for handling and clean up of contaminates

- Americans with disabilities checklist

PM: PREVENTIVE MAINTENANCE

- Cleaning schedule for air conditioning coils

- Guest room attendant cart inspection sheet

TR: TRAINING

- Job descriptions and requirements according to Americans with Disabilities Act

- CPR training checklist

P: PURCHASING

- Guest room linen specifications

- Room amenities and supply standards

HR: HUMAN RESOURCES

- Employee orientation checklist

- List of documents required for new employees

CO: COMMUNICATION

- Procedures for reporting room status to the front office

- Engineering work order forms

O: ORGANIZATION OF DEPARTMENT

- Hotel organization chart

- Guest room attendant cart stocking par 


\section{Limitations}

The sample was drawn from the population of hotels listed in The Directory of Hotel and Motel Companies published by The American Hotel and Motel Association. Therefore, results of the sudy cannot be generalized beyond the sample. 


\section{CHAPTER IV}

\section{RESULTS}

The purpose of this study was to identify important audit and checklist procedures of selected hotel housekeeping operations in the United States and develop a generic, customizable audit specific to this segment of the hotel industry. The applied objective of this study was to construct an operational audit that would be applicable and usable to all classifications of hotel companies.

Content analysis of the manuals and checklists revealed that a broad spectrum of information pertaining to hotel housekeeping operations was covered. In addition, the questions and statements in the material received varied significantly in length and detail. On one end of the spectrum was a two-page checklist of duties that a housekceper was expected to accomplish over the course of a daily work shift. The other end of the spectrum featured a 432-page manual which covered hotel history and gencral information, housekceping department goals and objectives through detailed job descriptions, task instructions and standard operating procedures of the department.

Due to the wide variance of hotel operations, the frequencies in the codes for analysis that are presented in the descriptive analysis tables (II. and III) may not fully indicate the importance of each category. Based on a variety of factors all hotels would not necessarily report incidents in each category or sub-category. Some of these variations could be due to the difference in classification, size, and level of service of the reporting hotel. For some of the hotels, the type of operation it is could explain the variation. As an 
example, a manual from a luxury property could have a detailed list of procedures for cleaning and stocking a mini-bar, while a budget hotel would not report on these procedures if the property did not have a mini-bar. In addition, vague or incomplete checklists of different hotels could explain variations. It is also possible that audits released from hotel companies did not include some details of their housekeeping deparments that they might have considered proprietary in nature.

In addition there are also wide variations within the same classification of hotels. For example, a nationally branded full service property reported 221 total incidents while a different hotel company in the same classification reported 125 . Possible explanations of these variances include the range of thoroughness of manuals from one company compared to other companies, and omission of proprietary information from manuals or audits sent to the researchers. Although the tables might not fulty indicate the importance of each category, particularly in the emphasis placed on each operating category, the codes and their frequencies show the general trends of practices in the set of manuals, audits, and checklists that were analyzed for the study on a comprehensive basis.

The summary of contents of major coded categories is ranked by percentages from the most frequently reported incidents to the least reported. The contents of subcategories are described and reported as a percentage of the major categories. 


\section{Table II}

Summary: Descriptive Statistics of Major Categories

\begin{tabular}{|cccc|}
\hline $\begin{array}{c}\text { Category } \\
\text { Code }\end{array}$ & $\begin{array}{c}\text { Total } \\
\text { Incidents }\end{array}$ & $\begin{array}{c}\text { Mean Number of } \\
\text { Incidents per Checklist }\end{array}$ & $\begin{array}{c}\text { Percent of Total } \\
\text { Coded Incidents }\end{array}$ \\
\hline C11 & 355 & 14.20 & 23.25 \\
C12 & 215 & 8.60 & 14.80 \\
O & 149 & 5.96 & 9.76 \\
I & 107 & 4.28 & 7.00 \\
HR & 99 & 3.96 & 6.48 \\
PM & 93 & 3.72 & 6.09 \\
L & 91 & 3.64 & 5.96 \\
CO & 88 & 3.52 & 5.76 \\
S & 88 & 3.52 & 5.76 \\
GS & 85 & 1.96 & 5.57 \\
TR & 65 & 2.60 & 4.26 \\
E & 49 & 1.96 & 3.21 \\
P & 43 & 1.72 & 2.82 \\
Total & $\mathbf{1 5 2 7}$ & & \\
& & & \\
\hline
\end{tabular}

Notes: CL1 $=$ Cleaning:Rooms, CL2 $=$ Cleaning: Public Space, $\mathrm{O}=$ Organization of Department, I=Inventory, $\mathrm{HR}=$ Human Resources, $\mathrm{PM}=$ Preventive Maintenance, $\mathrm{L}=$ Laundry, $\mathrm{CO}=$ Communications, $\mathrm{S}=\mathrm{Security} / \mathrm{Safety}, \mathrm{TR}=$ Training, $\mathrm{E}=$ Expenses, $\mathrm{P}=$ Purchasing

Descriptive Statistics of Categories and Sub-Categories

The top two categorics of $C L 1$, rooms cleaning and CL 2, public space cleaning accounted for $37.7 \%$ of total incidents reported by the companies. Hotels indicated that the cleaning of guestrooms was the most important factor in hotel housekeeping operations and the cleaning of public space was the second most important factor. Within the rooms cleaning category the most emphasis $(77.2 \%)$ was placed on the procedures of 
clcaning the living area and bathroom with the balance in the entry and bed/mattress subcategory.

Over half (50.7\%) of the public space cleaning category (C.12) was indicated to be in cleaning procedures of corridors, hallways, elevators, vending areas, and lobbies. The other $49.3 \%$ of CL 2 was related to public rest rooms, exterior, back of the house, and food and beverage outlet cleaning.

The third most important category reported by the hotel companies was organization of department $(\mathrm{O})$ with $9.8 \%$ of all incidents. Within that category issues pertaining to operations (06) was indicated to be the most important and accounted for $74.5 \%$ of the total in the category. In this sub-category the contents were related to lost and found articles, monitoring house tum, inspections, maintenance programs, key control, accessing guestrooms, and general housekeepers' daily duties. The remainder of the organization of department category addressed employee scheduling by sections, utilizing teams. housekeeping cart set-up, and supplies storage.

The next category of importance was in inventories (I) which accounted for $7.1 \%$ of all reponed incidents. Elements in that category consist of par lovels of housekeeping supplies, inventory management, and guestroom amenities with the most emphasis placed on par levels of supplies.

Almost four and a half percent $(4.5 \%)$ of total incidents were reported in the human resource (HR) category with $55.6 \%$ of that being comprised of employee orientation topics followed by scheduling procedures (19.2\%), employee relations (15.2\%), and the remainder in employee appearance and company hiring practices. 
The next level of importance was in the preventive maintenance (PM) category with $6.1 \%$ of total incidents reported. Almost half $(48.4 \%)$ were related to guestrooms and the rest to heating, ventilation, and cooling, safety procedures, and ongoing maintenance of the exterior and interior of the property.

Incidents reported in the laundry (L) category were $6.0 \%$ of total incidents, with guest laundry procedures being the most important $(45.6 \%)$ and in-house hotel procedures and facilities accounting for $30 \%$ of the total category. The remainder of the category addressed linen rotation and chemical use and handling procedures.

The category of communication (CO) was also considered important and comprised $5.8 \%$ of total incidents. The most important sub-category was repored to be guest communication (CO6) that makes up $36.5 \%$ of the category total. The balance of the category was divided between communication issues with guests and employees.

Safety and security (S) procedures were also $5.8 \%$ of the total reported incidents with the most important $(68.2 \%)$ being issues related to handling of hazardous materials and blood bome pathogens (S1).

The guest services category (GS) was $5.6 \%$ of total reported incidents. Guest services was a stand-alone, general category with no sub-categories which could explain its lower ranking in order of importance. The contents of this category included procedures of VIP guest issues, providing guest amenities, and handling special requests.

Training (TR) was an important category with $4.3 \%$ of all incidents. $78 \%$ of this category covered overall training procedures and policies of the hotels. The remainder of the category focused on the Americans with Disabilities Act (ADA). 
Two separate but related categories, expenses $(E)$ and purchasing $(P)$ comprised $6.0 \%$ of total reported incidents. The expense category had 5 sub-categories, cost control. budgeting, quality management, inspections, and age and inventory conditions. The most important areas in that category were cost control and inspections, which accounted for $55.1 \%$ of total expense incidents. $54.4 \%$ of the purchasing category was in procedures and standards of procuring guest supplies with the balance related to fumiture, fixture, and equipment purchasing.

Table III is a summary of descriptive statistics of coded categories and subcategories. The total incidents by category are listed and shown as a percentage of total incidents. The sub-categories'total incidents are listed and shown as a percentage of the major category. 
$\underline{\text { Table III }}$

Descriptive Statistics of Coded Categories and Sub-Categories

\begin{tabular}{|c|c|c|c|c|c|c|c|c|c|}
\hline Category & $\begin{array}{l}\text { Total } \\
\text { Category } \\
\text { Incidents }\end{array}$ & $\begin{array}{l}\text { Percent } \\
\text { of Total } \\
\text { Incidents }\end{array}$ & $\begin{array}{c}\text { Total } \\
\text { Sub- } \\
\text { Category } \\
\text { Incidents }\end{array}$ & $\begin{array}{l}\text { Percent } \\
\text { of Sub- } \\
\text { Calegory } \\
\text { Incidencs }\end{array}$ & Category & $\begin{array}{l}\text { Total } \\
\text { Category } \\
\text { Incidcrists }\end{array}$ & $\begin{array}{l}\text { Percent } \\
\text { of Total } \\
\text { Incidents }\end{array}$ & $\begin{array}{c}\text { Total } \\
\text { Sub- } \\
\text { Category } \\
\text { Incidents }\end{array}$ & $\begin{array}{l}\text { Percent } \\
\text { of Sub- } \\
\text { Category } \\
\text { Incidcnis }\end{array}$ \\
\hline CL1 & 355 & 23.3 & & & PM & 93 & 6.1 & & \\
\hline 1 & & & 153 & 43.1 & 4 & & & 26 & 28.0 \\
\hline$b$ & & & 121 & 34.1 & 5 & & & 20 & 21.5 \\
\hline $\mathrm{m}$ & & & 32 & 9.0 & 3 & & & 19 & 20.4 \\
\hline$g$ & & & 26 & 7.32 & 1 & & & 17 & 18.3 \\
\hline $\mathrm{e}$ & & & 23 & 6.5 & 6 & & & 6 & 6.5 \\
\hline CL2 & 215 & 14.8 & & & $\underline{\mathbf{L}}$ & 91 & 6.0 & & \\
\hline $\mathrm{c}$ & & & 61 & 28.4 & 3 & & & 41 & 45.6 \\
\hline I & & & 48 & 22.3 & 4 & & & 30 & 33.0 \\
\hline $\mathrm{g}$ & & & 34 & 15.8 & 1 & & & 9 & 9.9 \\
\hline$b$ & & & 30 & 14.0 & 6 & & & 6 & 6.7 \\
\hline$\Gamma$ & & & 29 & 13.5 & 2 & & & 5 & 5.5 \\
\hline 0 & & & 4 & - & & & & & \\
\hline & & & & & $\mathrm{CO}$ & 88 & 5.8 & & \\
\hline$\underline{\underline{O}}$ & 149 & 9.8 & & & 5 & & & 32 & 36.4 \\
\hline 6 & & & 111 & 74.5 & 3 & & & 20 & 22.7 \\
\hline 4 & & & 14 & 9.4 & 2 & & & 18 & 20.5 \\
\hline 5 & & & 8 & 5.4 & 6 & & & 8 & 9.0 \\
\hline 2 & & & 7 & 4.2 & 1 & & & 6 & 6.8 \\
\hline 3 & & & 6 & 4.) & 4 & & & 4 & 4.5 \\
\hline \multirow[t]{2}{*}{1} & & & 3 & 2.0 & & & & & \\
\hline & & & & & $\underline{S}$ & 88 & 5.8 & & \\
\hline$\underline{I}$ & 107 & 7.0 & & & I & & & 43 & 48.9 \\
\hline 3 & & & 50 & 46.7 & 3 & & & 28 & 31.8 \\
\hline 2 & & & 34 & 31.8 & 2 & & & 17 & 19.3 \\
\hline \multirow[t]{2}{*}{1} & & & 23 & 21.5 & & & & & \\
\hline & & & & & GS & 88 & 5.8 & & \\
\hline HR & 99 & 6.5 & & & & & & & \\
\hline 1 & & & 55 & 55.6 & TR & 65 & 4.3 & & \\
\hline 2 & & & 19 & 19.2 & 1 & & & 34 & 52.3 \\
\hline 5 & & & 15 & 15.5 & 2 & & & 18 & 27.7 \\
\hline 4 & & & 6 & 6.1 & 3 & & & 13 & 20.0 \\
\hline 3 & & & 4 & 4.0 & & & & & \\
\hline
\end{tabular}




\begin{tabular}{|c|c|c|c|c|c|c|c|c|c|}
\hline Calegory & $\begin{array}{c}\text { Tutal } \\
\text { Category } \\
\text { Incidents }\end{array}$ & $\begin{array}{c}\text { Percent } \\
\text { Of Tolal } \\
\text { incidents }\end{array}$ & $\begin{array}{c}\text { Tolal } \\
\text { Sub- } \\
\text { Calegony } \\
\text { incidenis }\end{array}$ & $\begin{array}{c}\text { Percent } \\
\text { of Sub- } \\
\text { Category } \\
\text { Incidents }\end{array}$ & Category & $\begin{array}{c}\text { Total } \\
\text { Category } \\
\text { Incidents }\end{array}$ & $\begin{array}{c}\text { Percent } \\
\text { of Total } \\
\text { Incidcris }\end{array}$ & $\begin{array}{c}\text { Total } \\
\text { Sub- } \\
\text { Category } \\
\text { Incidents }\end{array}$ & $\begin{array}{c}\text { Percent } \\
\text { of Sub- } \\
\text { Catigory } \\
\text { Incidents }\end{array}$ \\
\hline $\mathbf{E}$ & 49 & 2.21 & & & $\mathbf{P}$ & 43 & 2.8 & & \\
\hline 1 & & & 14 & 28.6 & 2 & & & 14 & 32.6 \\
\hline 4 & & & 13 & 26.5 & 1 & & & 13 & 30.2 \\
\hline 3 & & & 10 & 20.4 & 3 & & & 5 & 11.6 \\
\hline 2 & & & 7 & 14.2 & & & & & \\
\hline 5 & & & 5 & 10.2 & & & & & \\
\hline & & & & & & & & & \\
\hline
\end{tabular}

Category codes: CLI=Gues!room cleaning. $]=$ Living urea, $b=$ Bathroom, m=Mattress and bed $g=$ General, $e=$ Entry CL2=Public space cleaning, $c=$ corridors, stairs, vending, elevator $]=$ Lobby, $g=$ General, $b=$ Back of housc, $c=$ Extenor, Frestrooms, $0=$ Outlets,

$\underline{\underline{Q}}=$ Organization of cepartment, $\}=$ Teams. $2=$ Scheduling of sections. $3=$ Organizalton char, 4 =carts. $5=$ Storage, $6=$ Operations

$\underline{1}=$ Inventories, $\mathrm{I}=$ Par levels, $2=$ inventory management, $]=$ guestroom amenities. $\mathbf{H B}=\mathrm{Human}$ resources, $1=$ Orietauon,

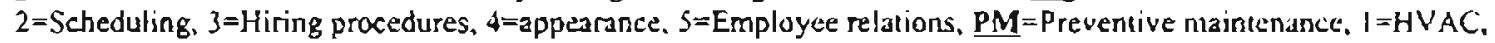

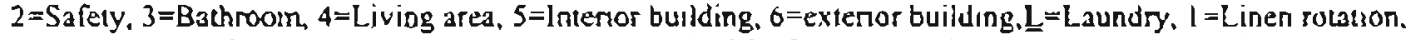
$2=$ chemicals, $3=$ Guest, $4=$ In house laundry, $5=$ general, $\mathrm{CO}=$ Communication, $1=$ Rooms control, $2=$ Butween department. $3=$ =vork orders. $4=$ Follow-up, $s=$ Guest, $6=$ employees. $s=S e c u r i t y /$ safety. $1=$ HAZCOM/MDSD/blood borme pathogens, 2=guestroom security/safery, $3=$ General, GS=Guest services, $\underline{\text { TR}=T r a i n i n g, ~ I=O p e r a t i o n s . ~}$ 2=administration, $3=$ guest service, E=Expenses. $1=$ Cost control, $2=$ Budgering. $3=$ Quality management, $4=$ Inspectsons, $5=$ Age \& condition of inventory. $\underline{P}=$ Purchasing, $\{=$ Linen, $2=$ Guestroom supplies. $3=$ Amenities, $4=F F \& E$ 
Exhibit 2.1 is the complete hotel housekeeping operational audit questionnaire.

Exbibit 2.1

Hotel Housekeeping Operational

Audit Questionnaire

\begin{tabular}{|c|c|c|c|c|}
\hline HUMAN RESOURCES & $\underline{\underline{Y E S}}$ & $\underline{\mathrm{NO}}$ & $\underline{\mathrm{NA}}$ & $\begin{array}{l}\text { Comments/ } \\
\text { Follow-up Action }\end{array}$ \\
\hline \multicolumn{5}{|l|}{ Orientation } \\
\hline \multicolumn{5}{|l|}{$\begin{array}{l}\text { Is there a formal orientation } \\
\text { program? }\end{array}$} \\
\hline \multicolumn{5}{|l|}{$\begin{array}{l}\text { Do you document the employees' } \\
\text { attendance? }\end{array}$} \\
\hline \multicolumn{5}{|l|}{$\begin{array}{l}\text { Are training manuals available for } \\
\text { each employee function? }\end{array}$} \\
\hline \multicolumn{5}{|l|}{$\begin{array}{l}\text { Do you have a language barrier } \\
\text { program? }\end{array}$} \\
\hline \multicolumn{5}{|l|}{$\begin{array}{l}\text { Do you have policies/procedures } \\
\text { regarding the following issues: }\end{array}$} \\
\hline \multicolumn{5}{|l|}{ employee meetings? } \\
\hline \multicolumn{5}{|l|}{ vacations? } \\
\hline \multicolumn{5}{|l|}{ paydays? } \\
\hline \multicolumn{5}{|l|}{ unauthorized absence from work? } \\
\hline \multicolumn{5}{|l|}{ personal telephone usage'? } \\
\hline \multicolumn{5}{|l|}{ off-duty employees? } \\
\hline employee visitors? & & & & \\
\hline \multicolumn{5}{|l|}{ tardiness? } \\
\hline \multicolumn{5}{|l|}{ smoking? } \\
\hline \multicolumn{5}{|l|}{ bulletin board? } \\
\hline \multicolumn{5}{|l|}{ personal packages? } \\
\hline \multicolumn{5}{|l|}{ lunch/ break periods? } \\
\hline \multicolumn{5}{|l|}{ clock/check-in? } \\
\hline \multicolumn{5}{|l|}{ beginning/ending shift duties? } \\
\hline \multicolumn{5}{|l|}{ personal conduct? } \\
\hline \multicolumn{5}{|l|}{ guest service skills? } \\
\hline \multicolumn{5}{|l|}{ uniforms? } \\
\hline \multicolumn{5}{|l|}{ Scheduling } \\
\hline $\begin{array}{l}\text { Are daily room assignment sheets } \\
\text { available in advance? }\end{array}$ & & & & \\
\hline
\end{tabular}




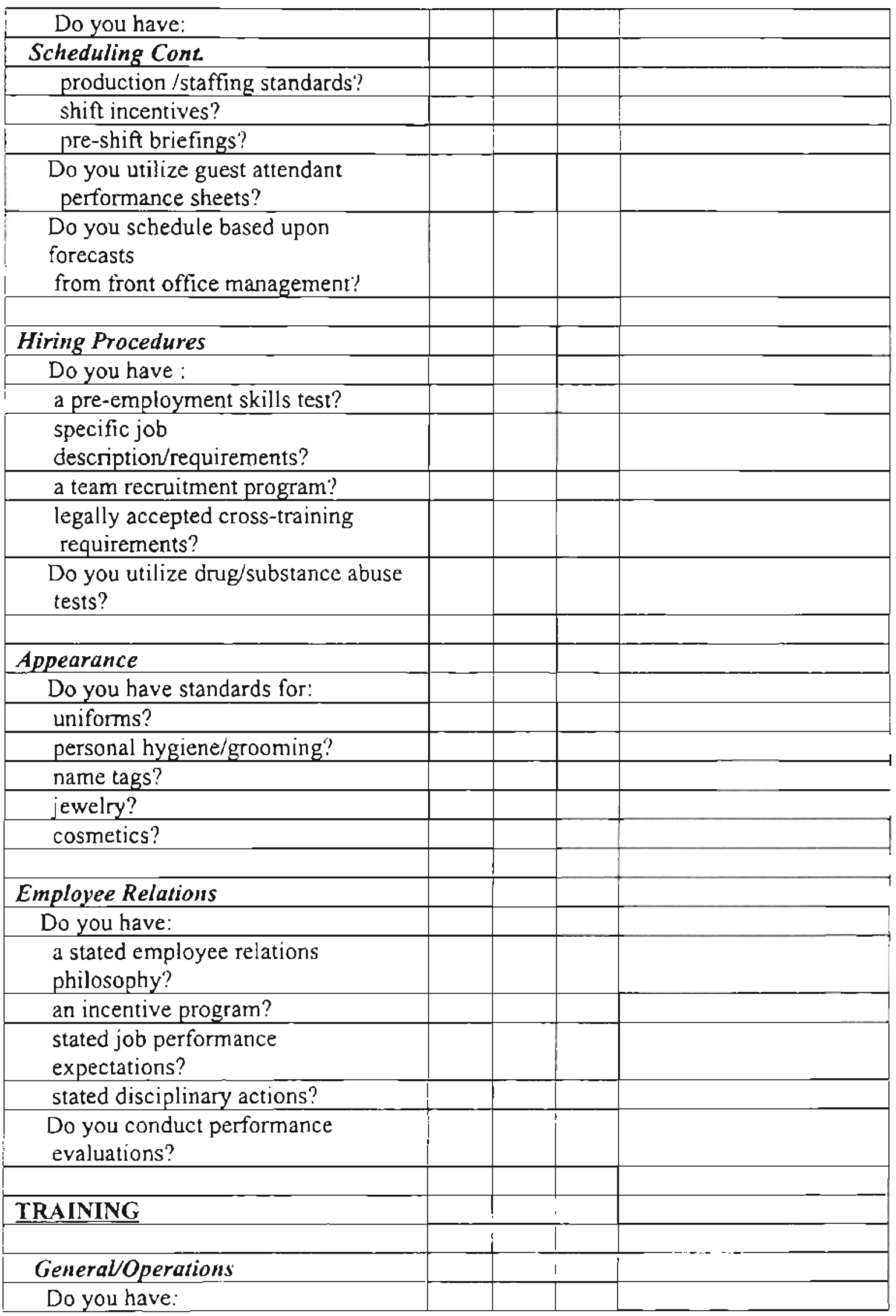




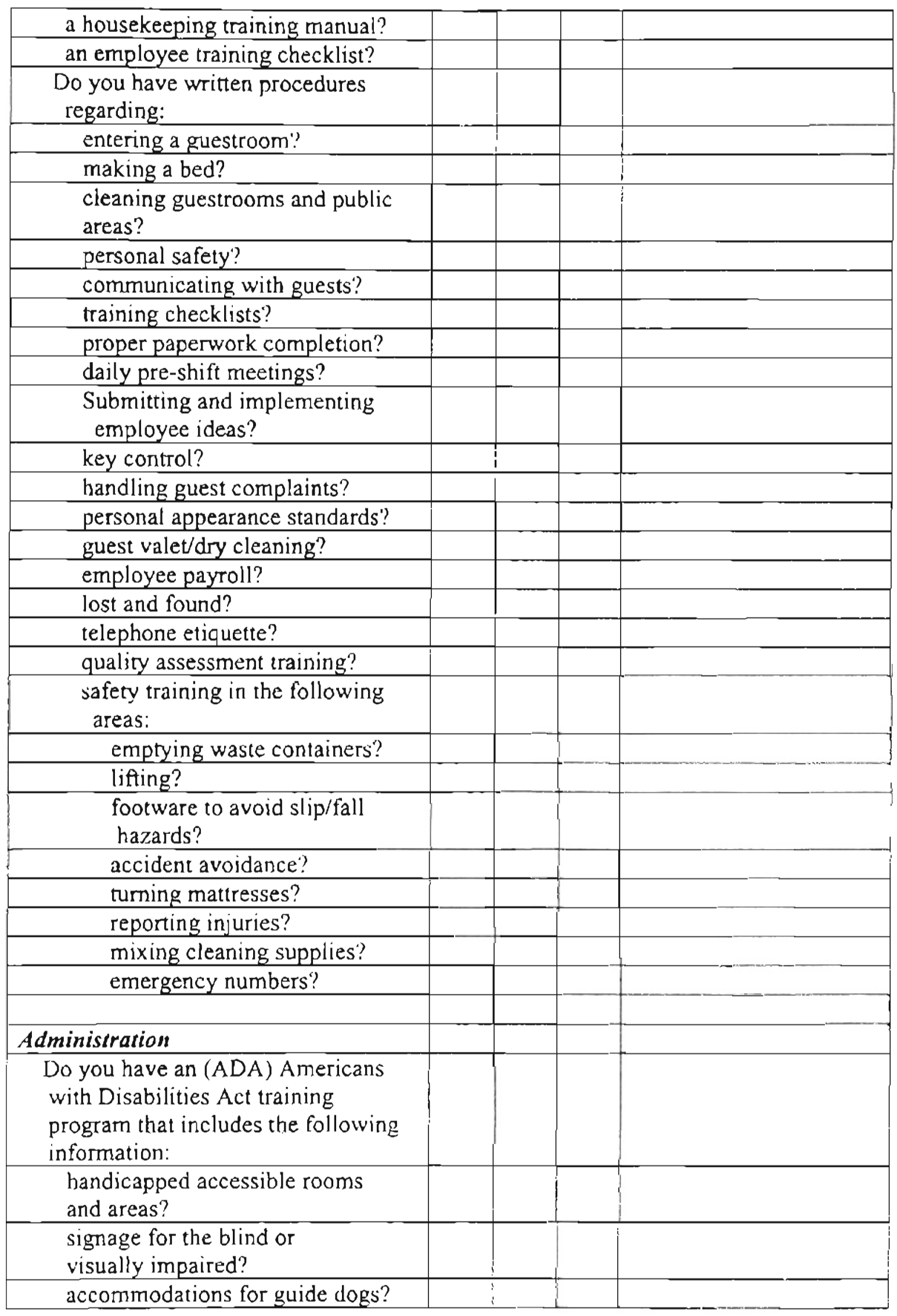




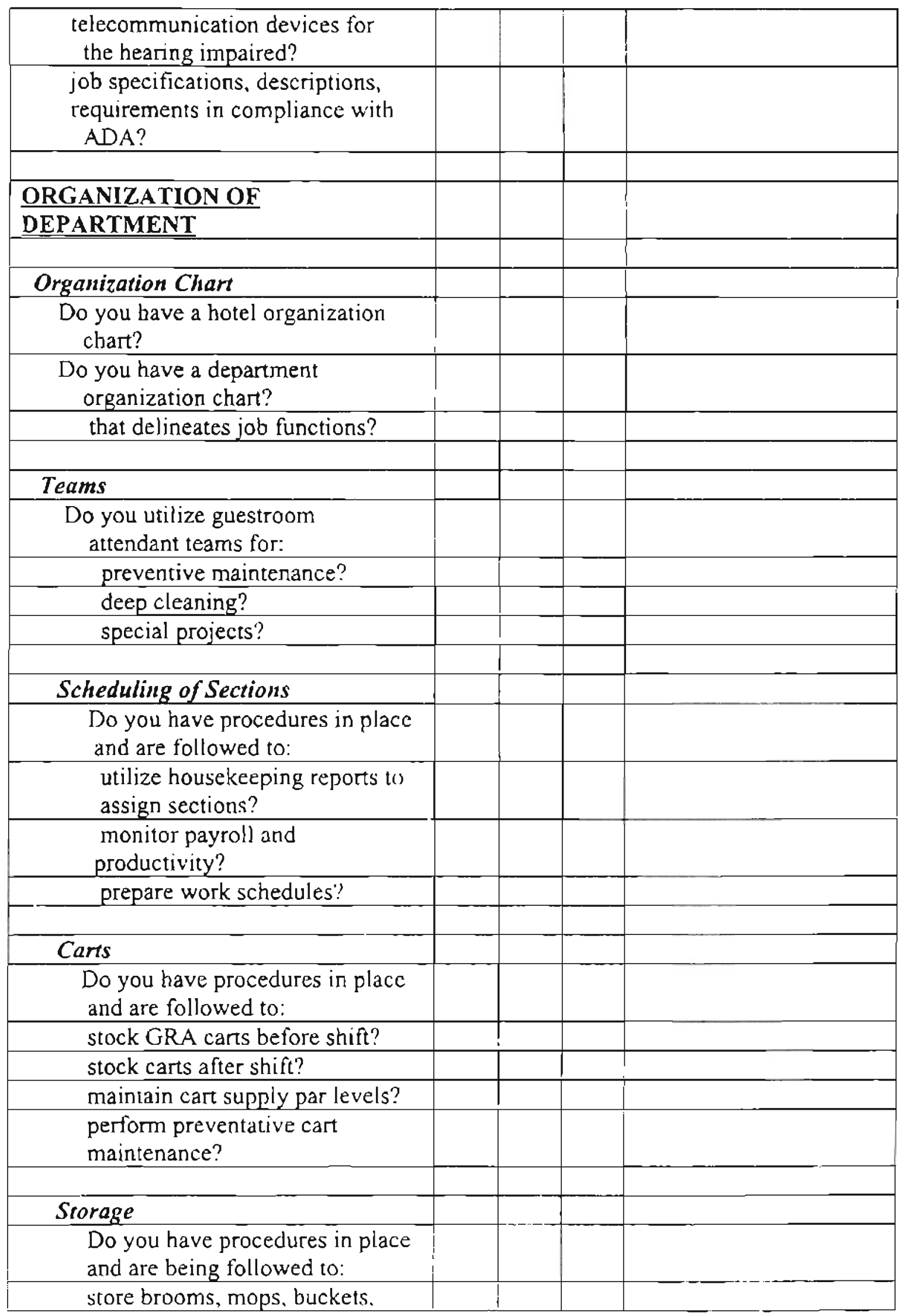




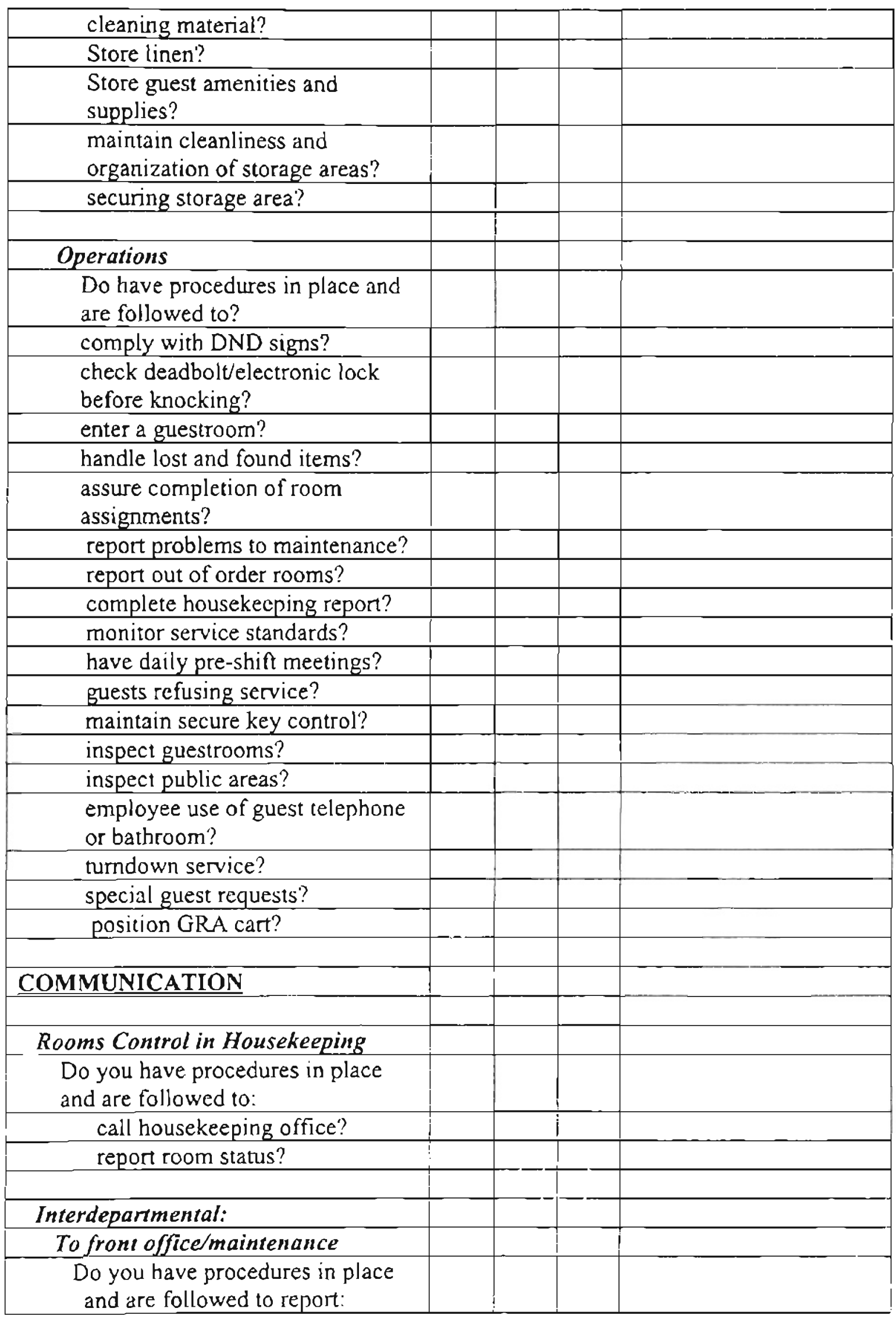




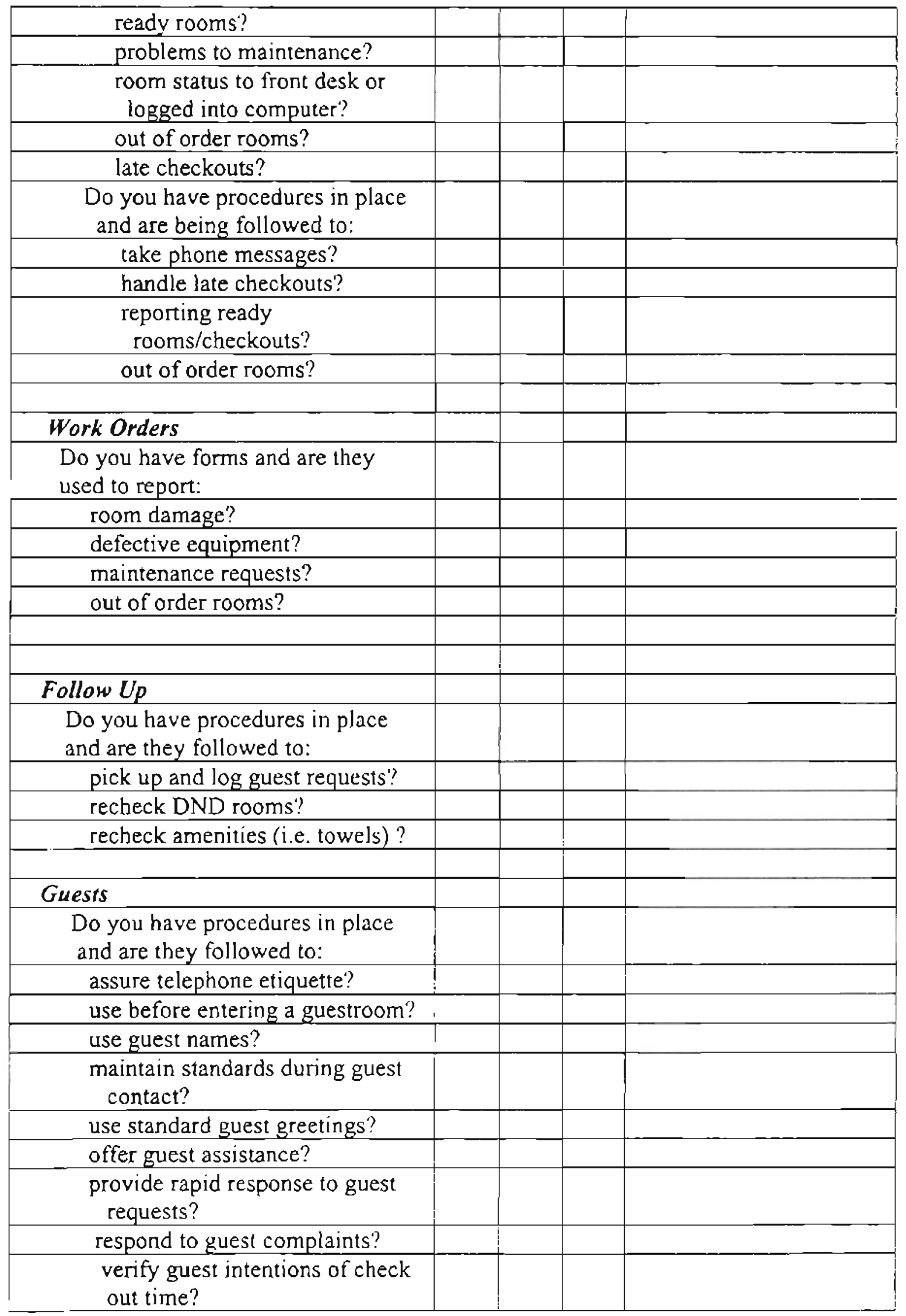




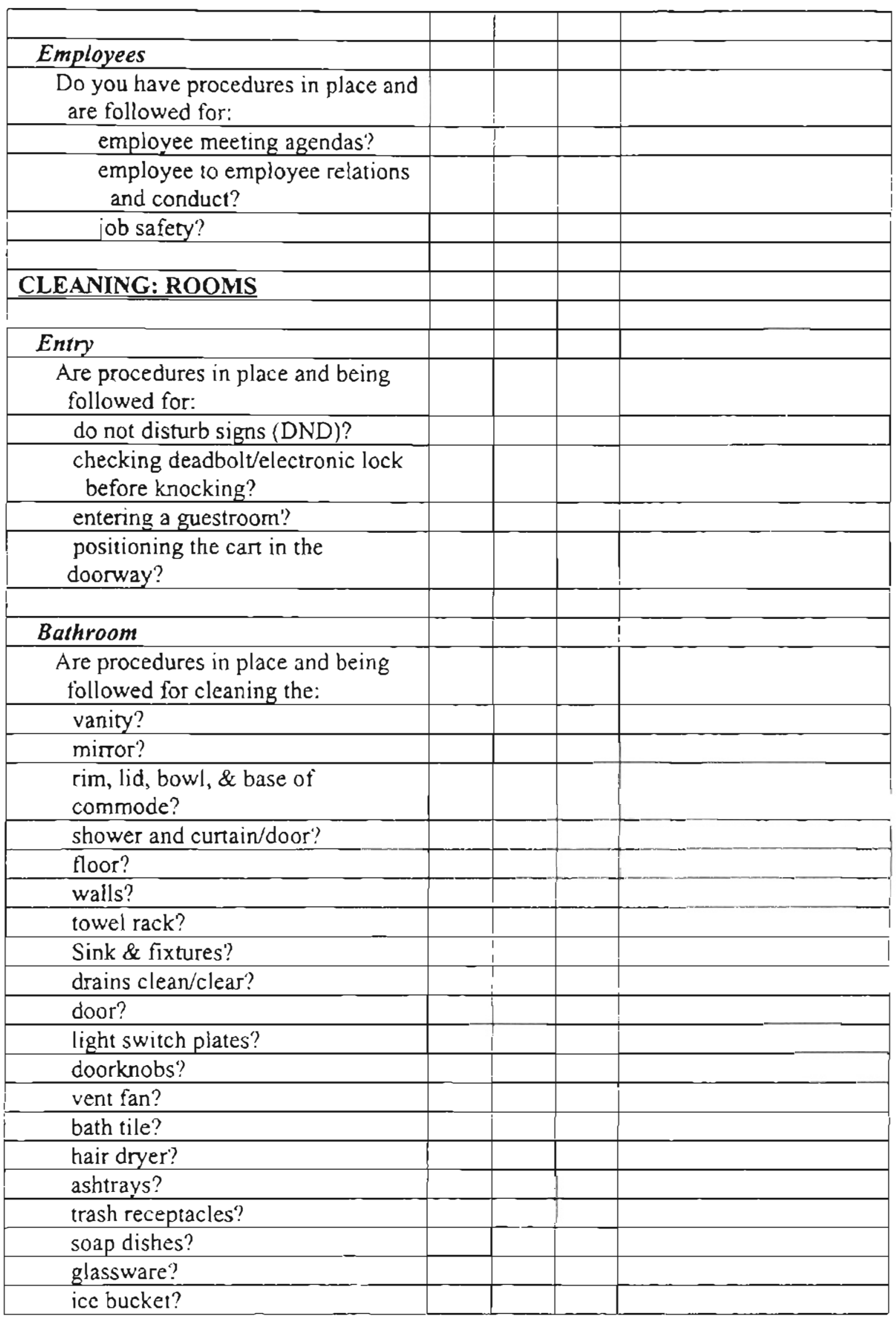




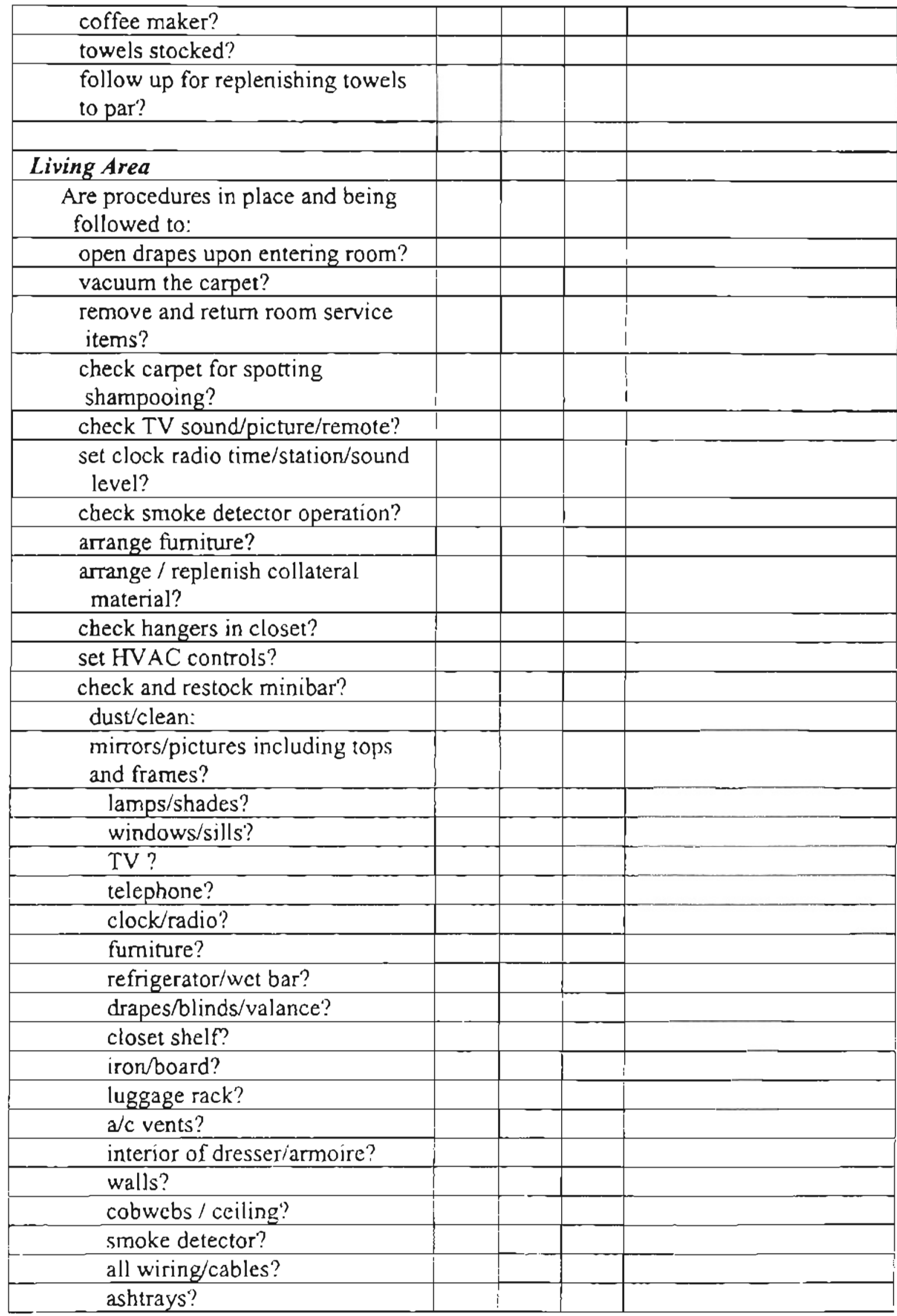




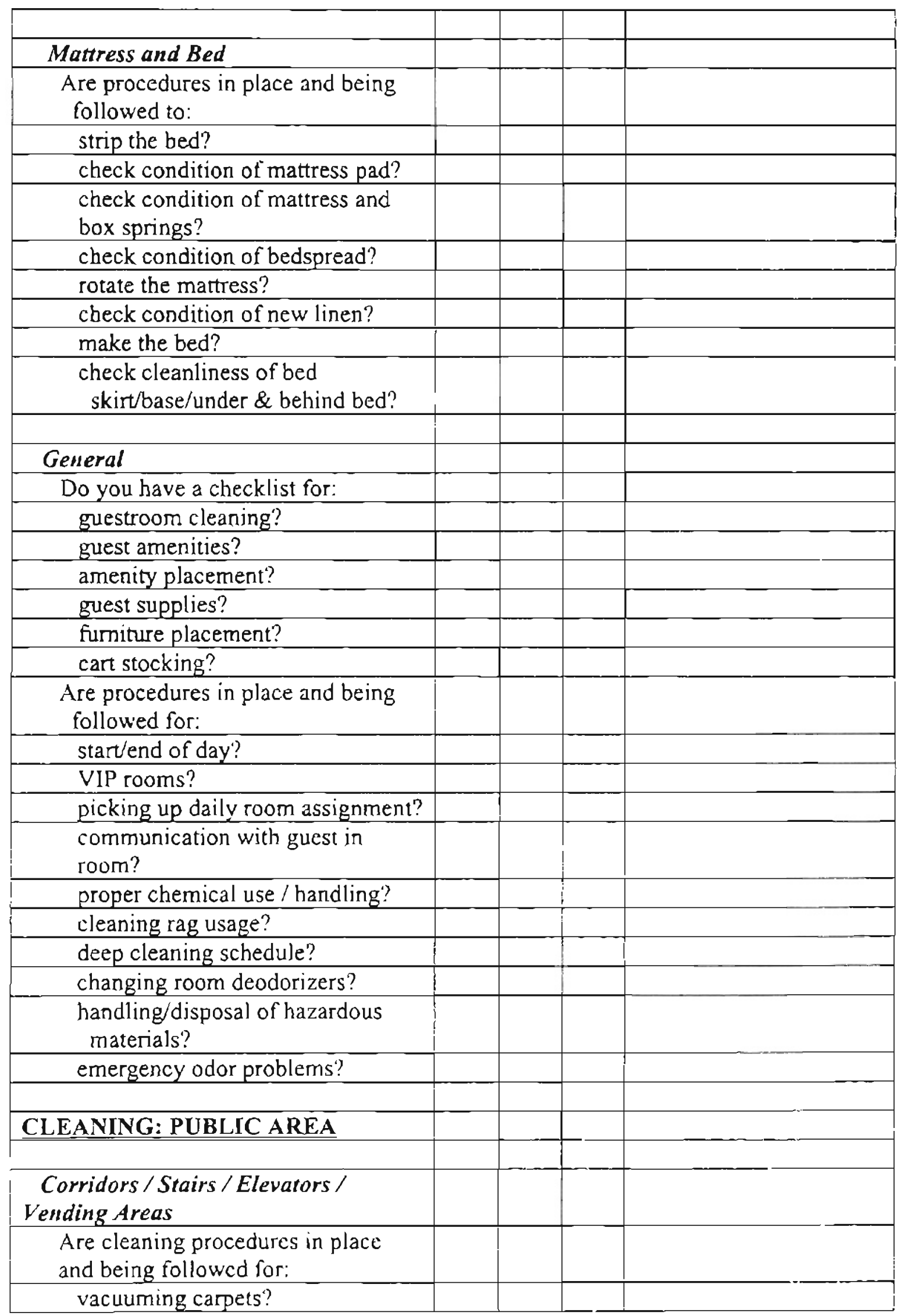




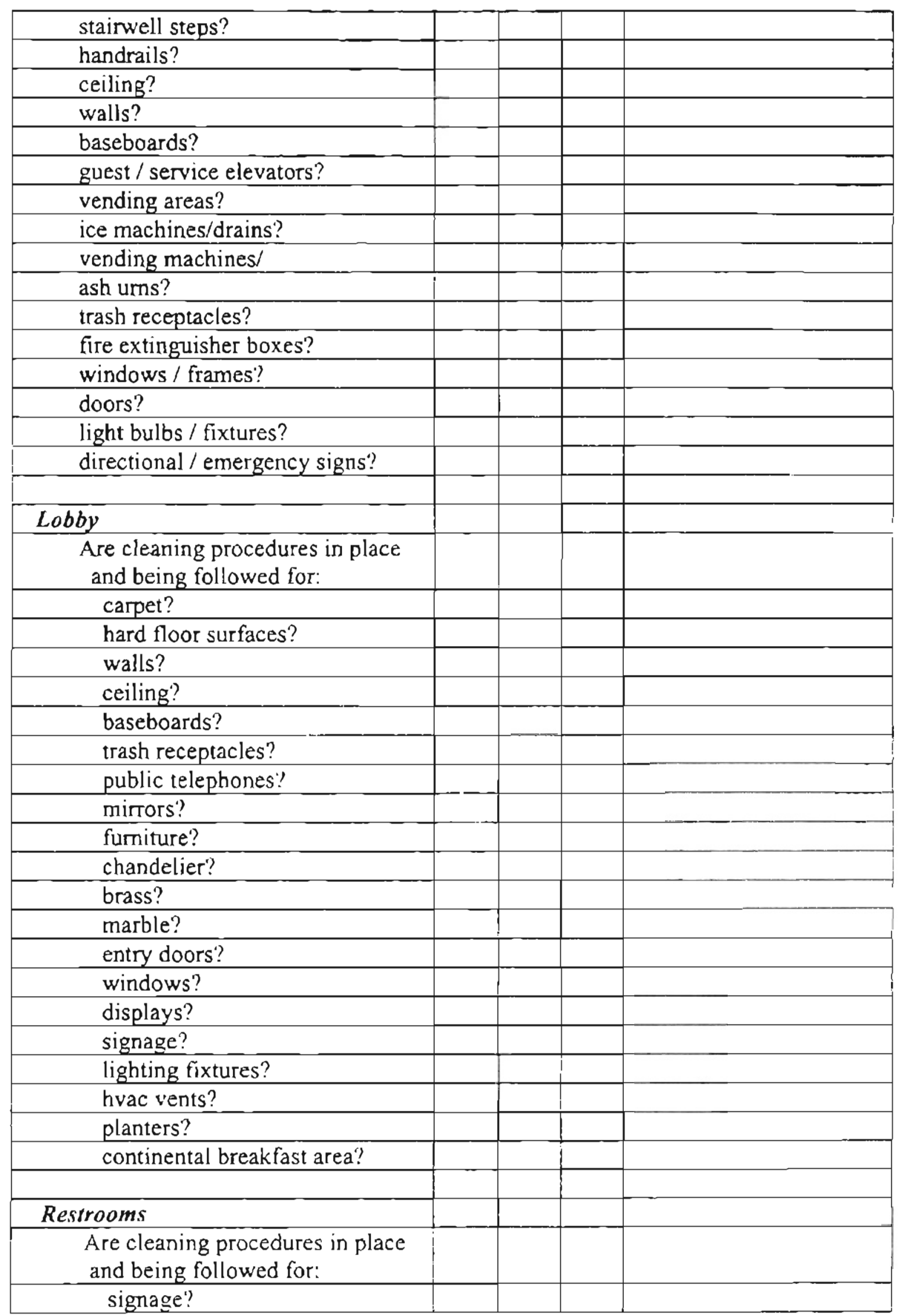




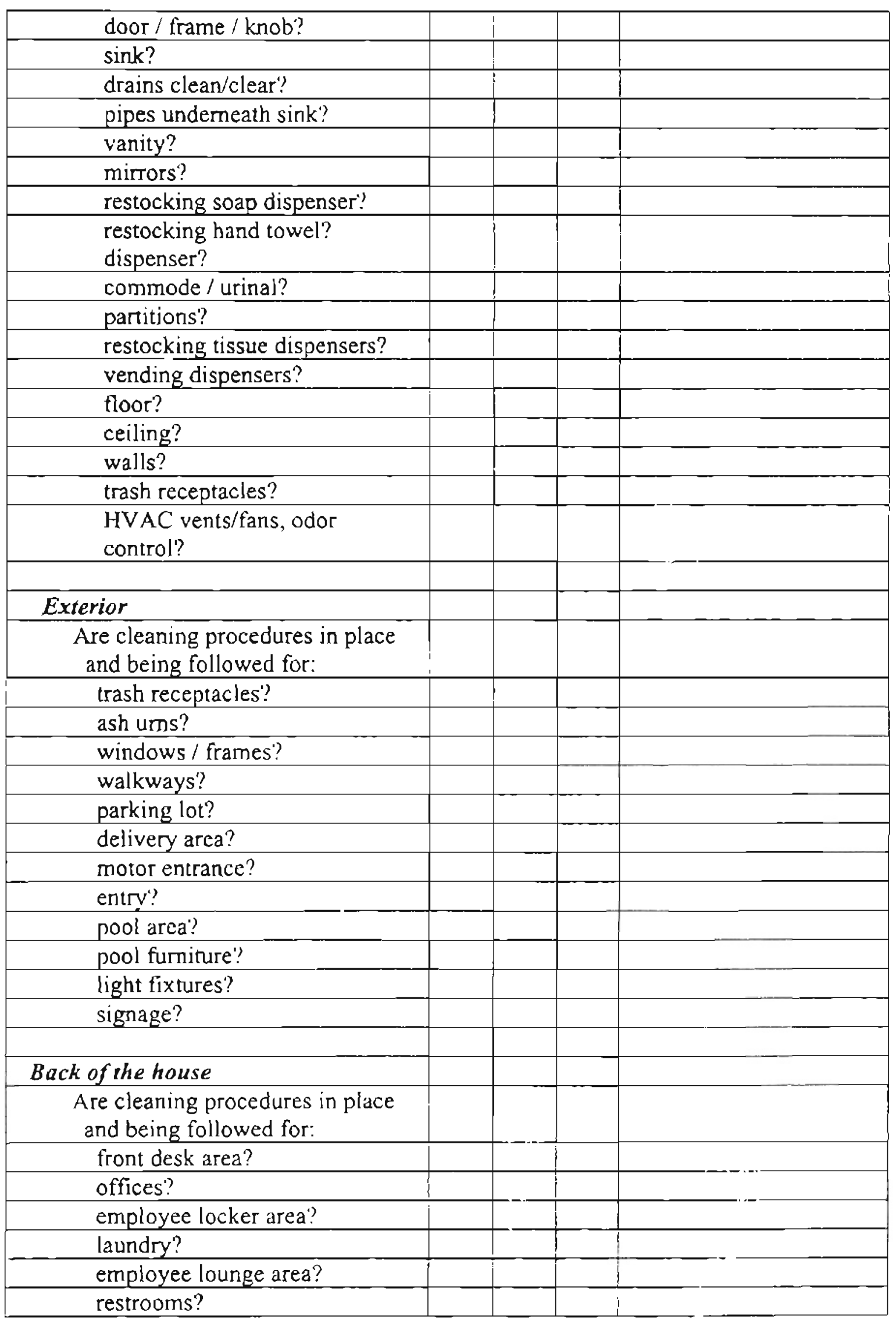




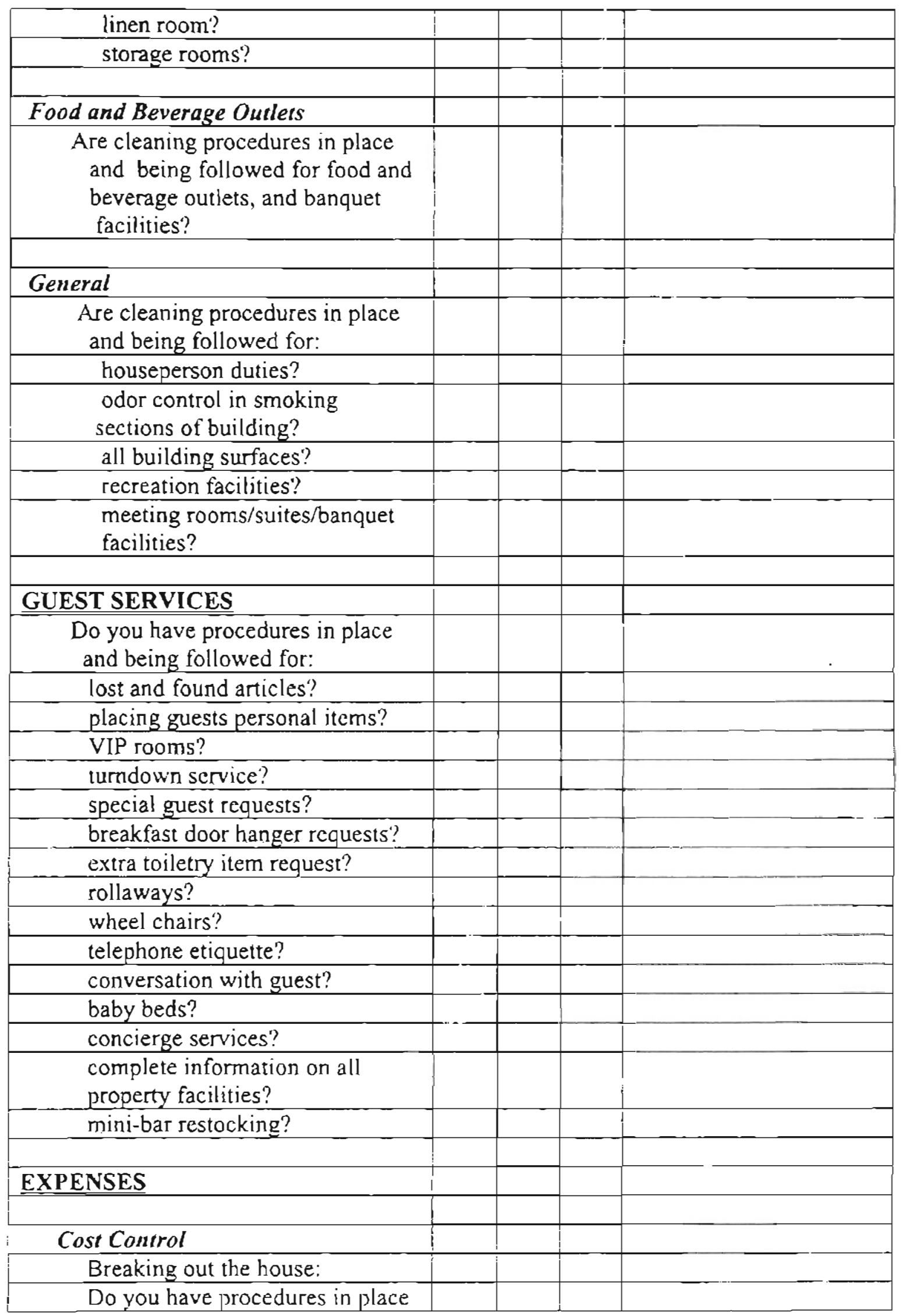




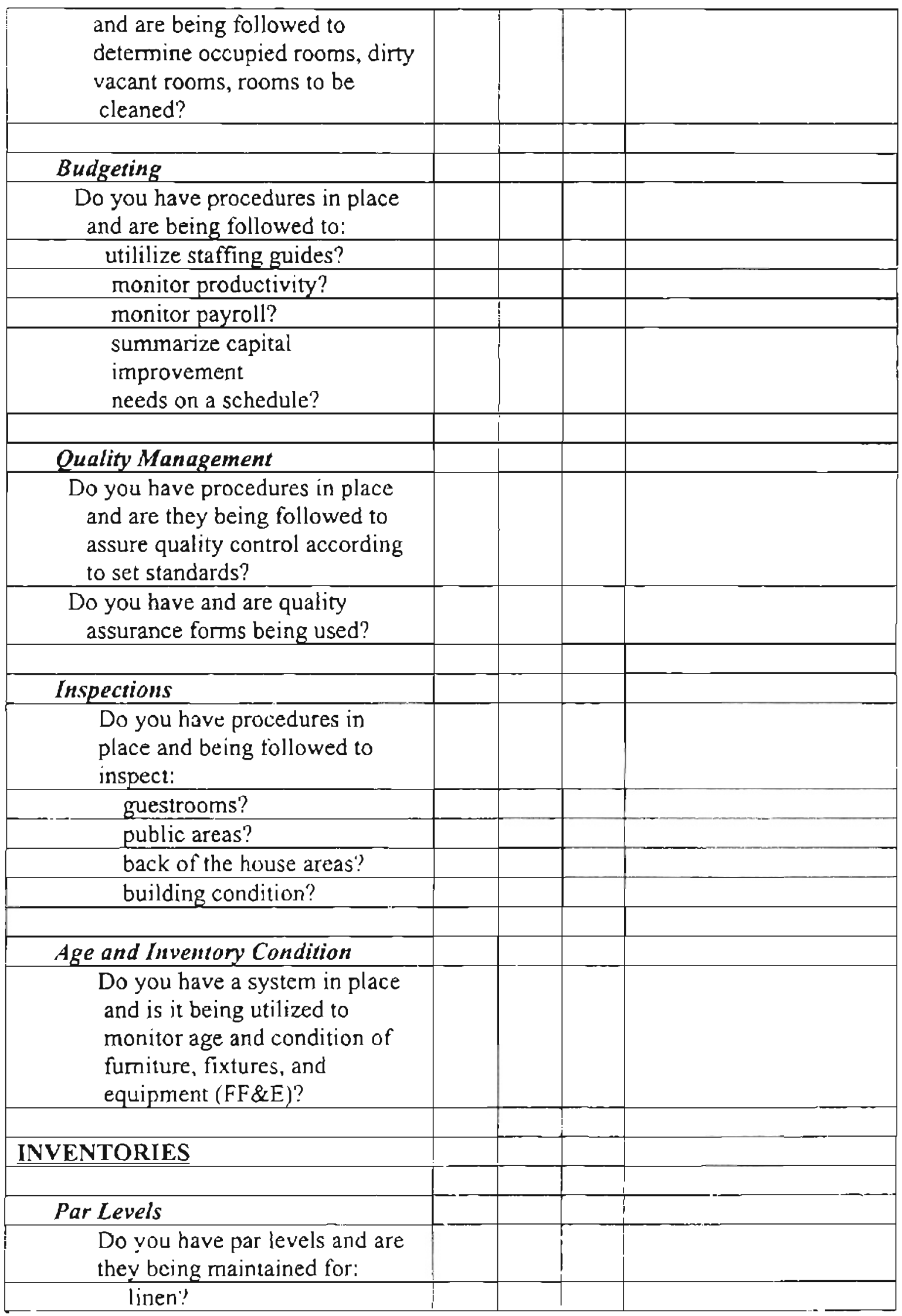




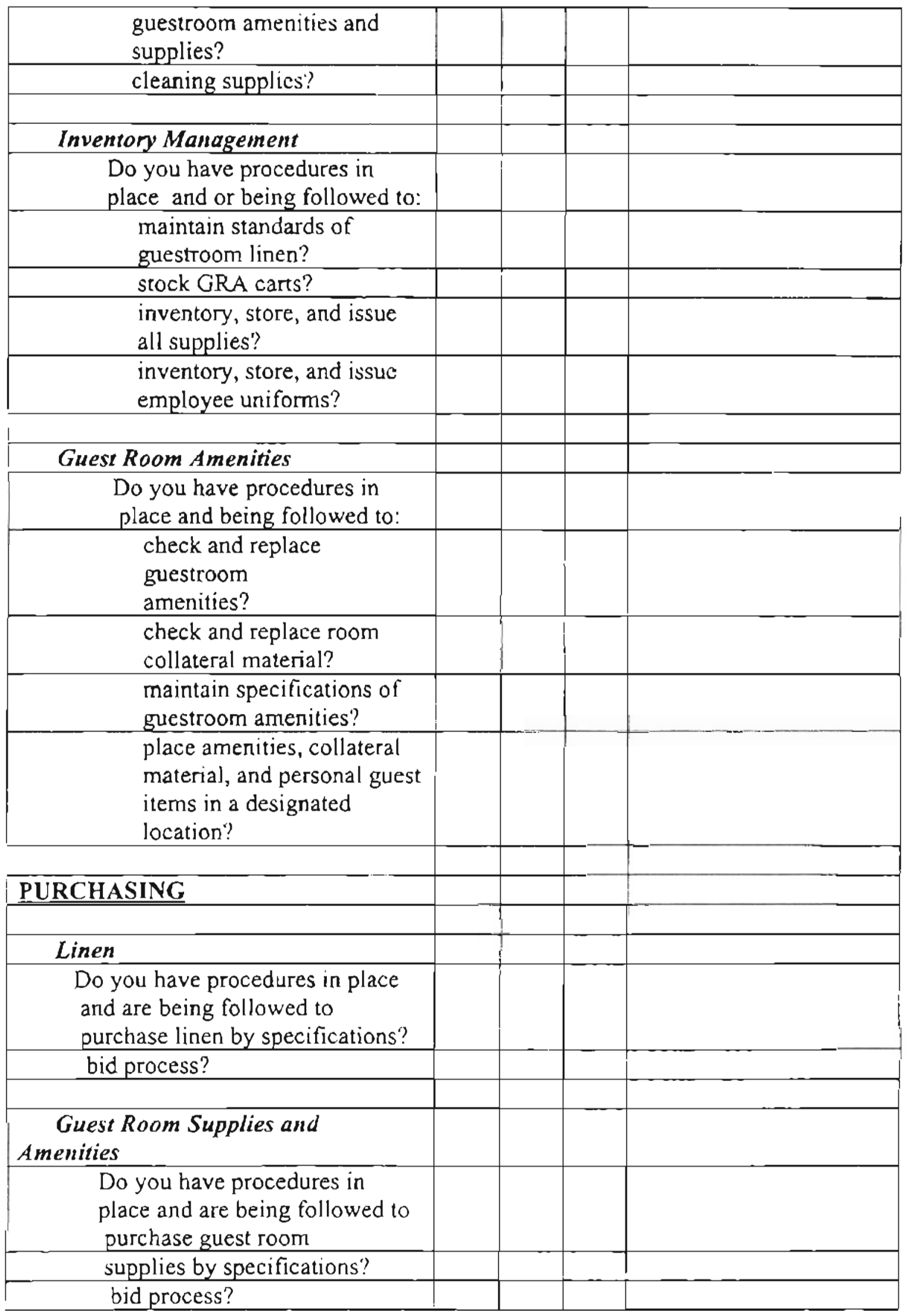




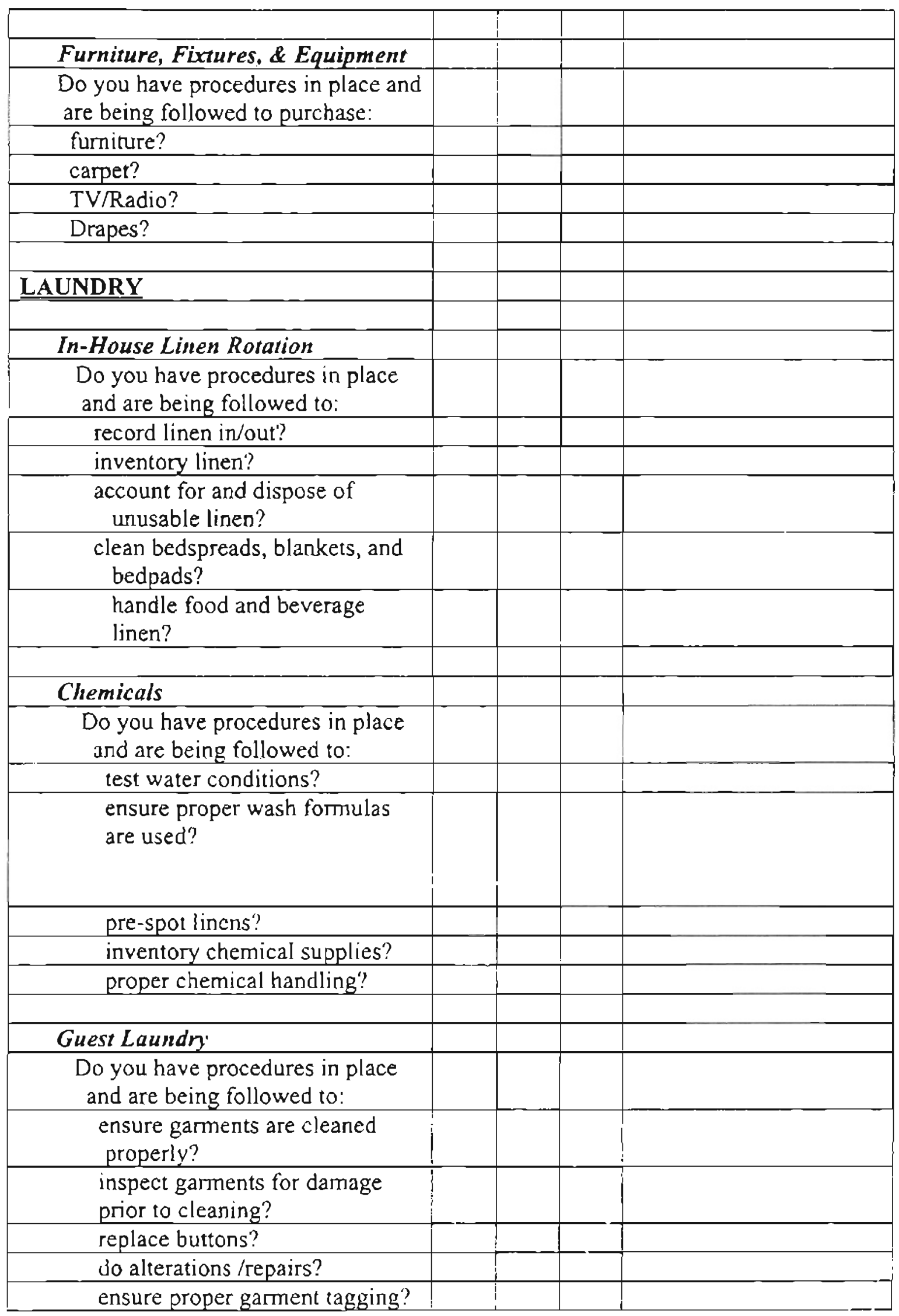




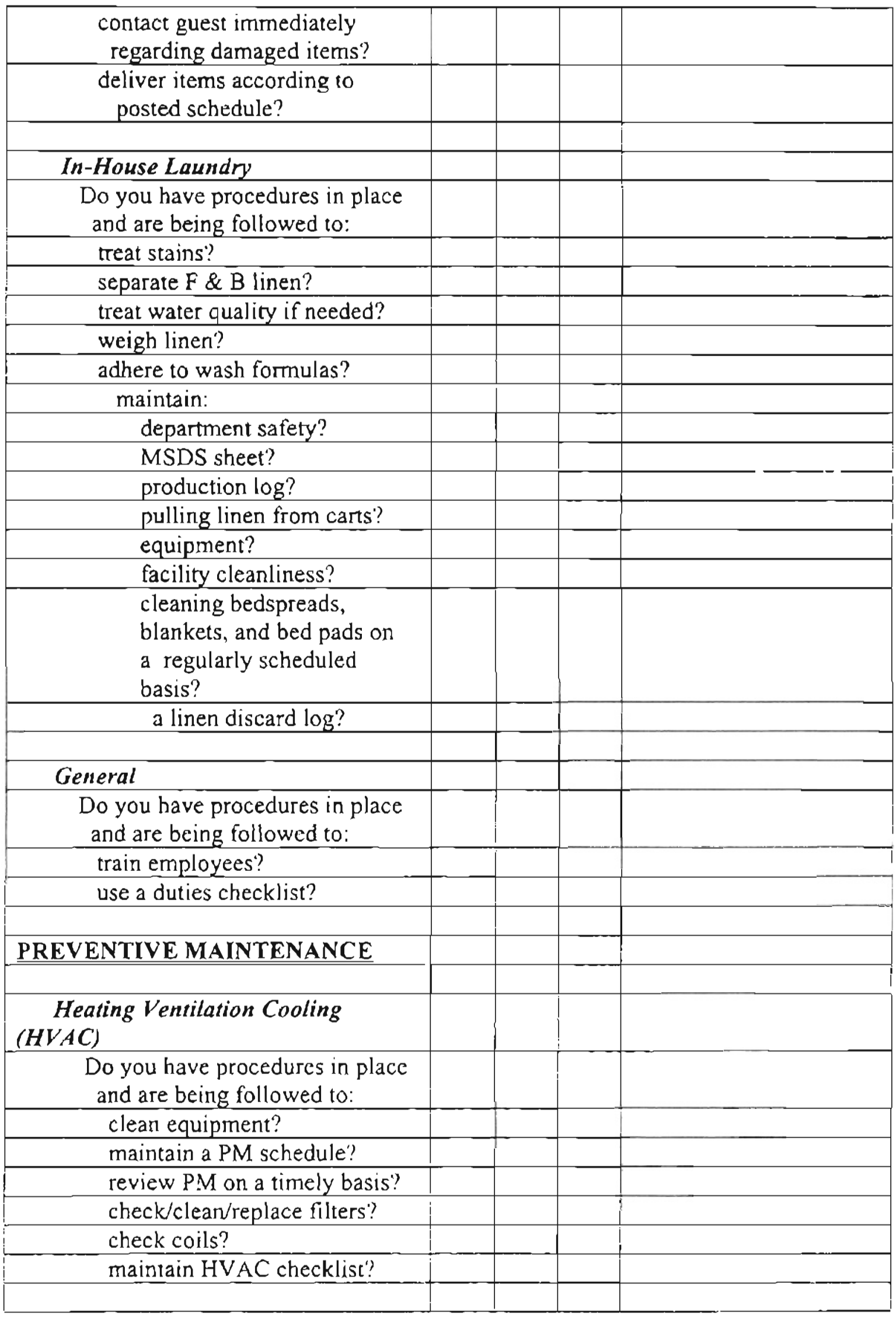




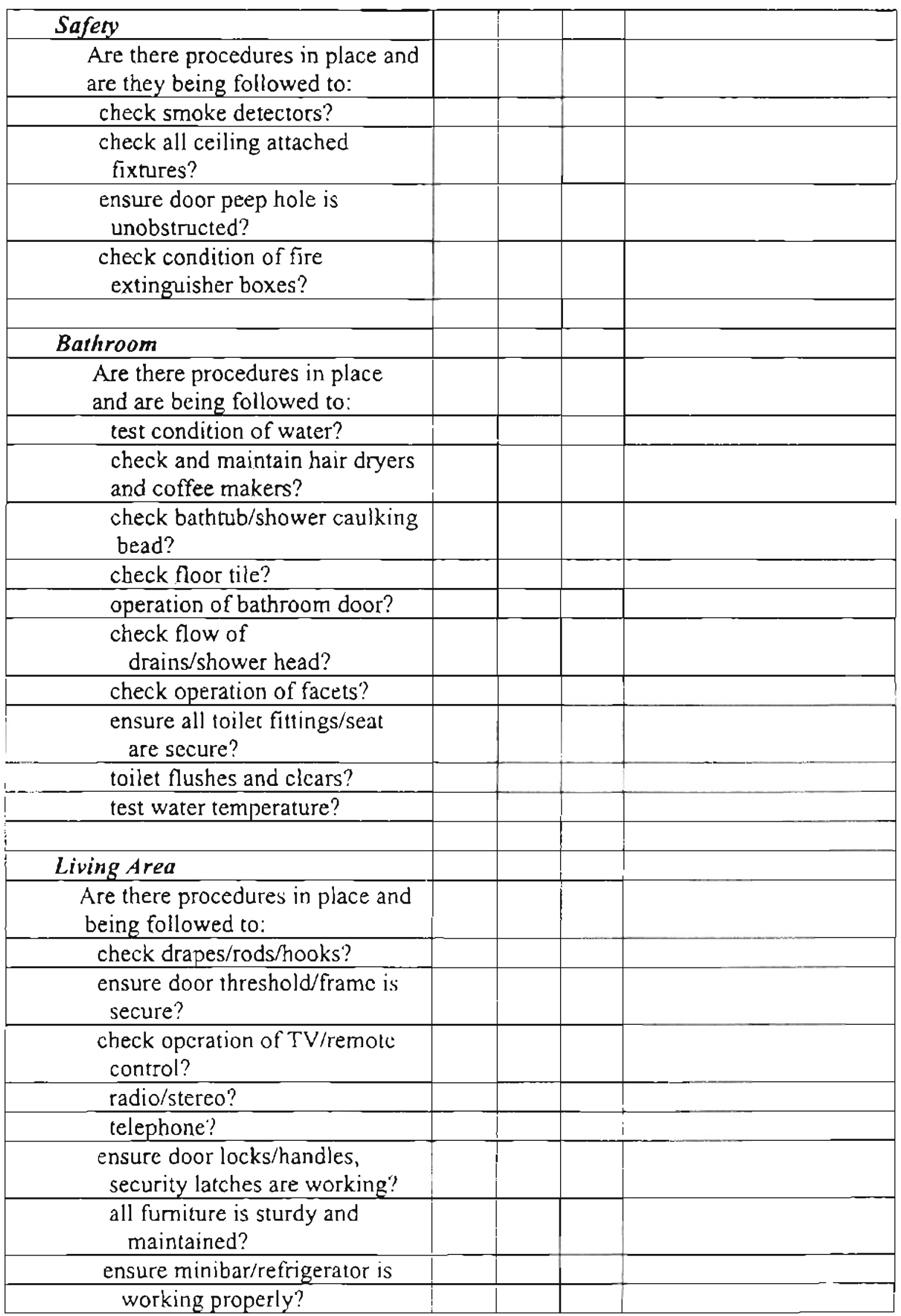




\begin{tabular}{|c|c|c|c|c|}
\hline $\begin{array}{c}\text { ensure timely mattress } \\
\text { rotation? }\end{array}$ & & & & \\
\hline $\begin{array}{c}\text { check closet door operation? } \\
\text { carpets are deep cleaned or } \\
\text { timely basis? }\end{array}$ & & & & \\
\hline $\begin{array}{c}\text { check condition of all } \\
\text { electrical cords? }\end{array}$ & & & & \\
\hline Interior Building & & & & \\
\hline $\begin{array}{c}\text { Are there procedures in place and } \\
\text { being followed to maintain: }\end{array}$ & & & & \\
\hline door, wall, and ceiling finish? & & & & \\
\hline room attendant carts? & & & & \\
\hline corridor lighting? & & & & \\
\hline vacuums? & & & & \\
\hline banquet and meeting rooms? & & & & \\
\hline hotel entrance, lobby? & & & & \\
\hline health club facilities? & & & & \\
\hline & & & & \\
\hline Exterior Building & & & & \\
\hline $\begin{array}{c}\text { Are there procedures in place and } \\
\text { being followed to maintain: }\end{array}$ & & & & \\
\hline parking lot/curbing? & & & & \\
\hline landscaping? & & & & \\
\hline pool area? & & & & \\
\hline outdoor furnishings? & & & & \\
\hline signage? & & & & \\
\hline walkways? & & & & \\
\hline & & & & \\
\hline SAZCOMT/SECURITY & & & \\
\hline Pathogens & & & \\
\hline
\end{tabular}




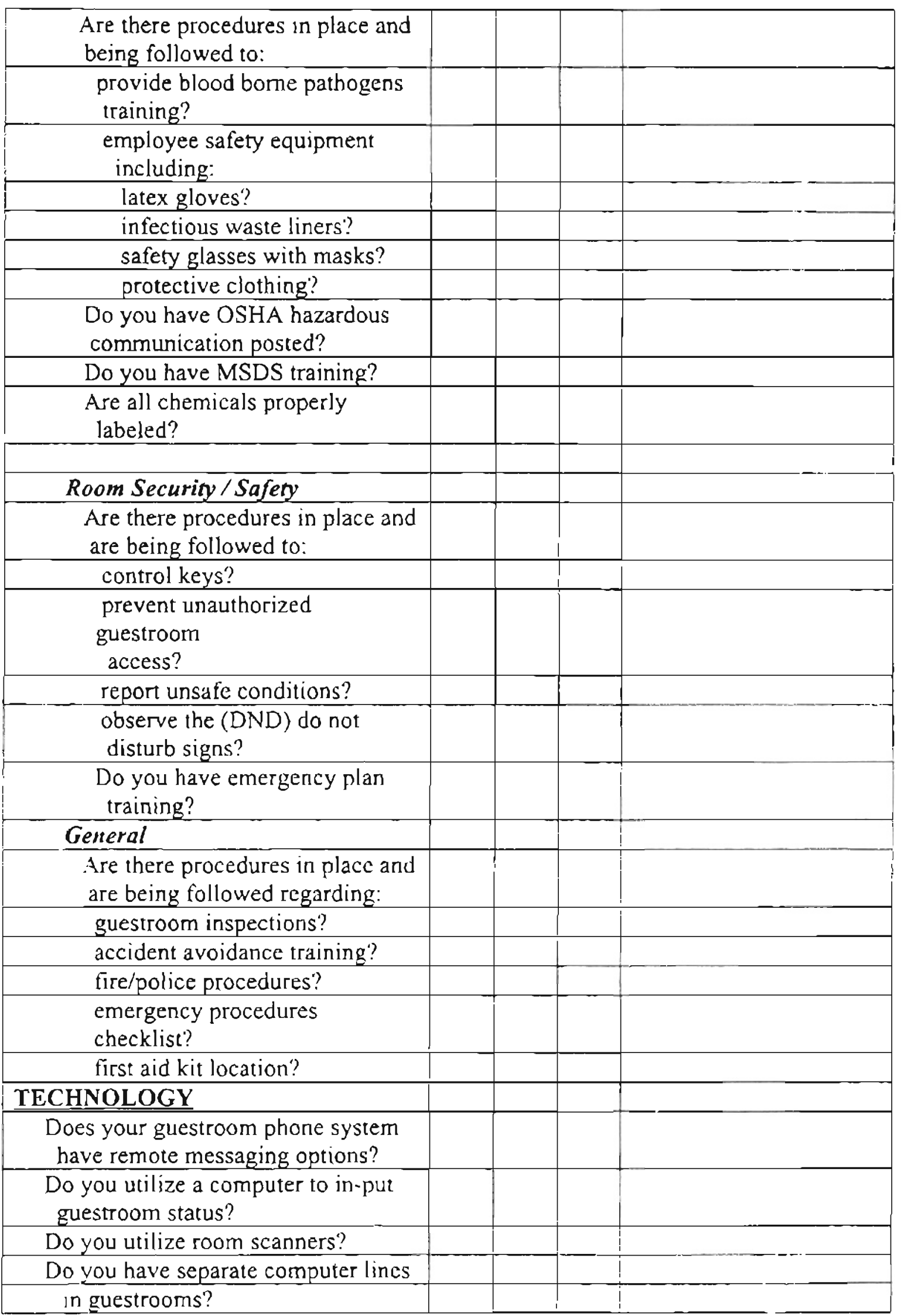




\section{CHAPTER V}

Summary, Conclusions, and Recommendations

Summary

The purpose of this study was to identify important audit and checklist procedures of selected hotel housekeeping operations in North America and develop a generic, customizable operational audit specific to this segment of the hotel industry. The objectives of this study were:

1) research operational pattems and practices of hotel housekeeping depanments which reflected the most important features utilized in the industry.

2) integrate this information into a complete operational audit system.

3) develop a self-administered audit questionnaire that hotel employees. management, and internal or external auditors of all classifications of hotel companies could implement.

The review of literature consisted of eight major sections, (1) brief history of the lodging industry, (2) hotel housekeeping management structure, (3) hotel housekeeping functions, (4) hotel management strategies, (5) role of operational auditing in hospitality management, (6) functions of an operational audit, (7) goals of an audit, and (8) format and implementation of an operational audit. 
The population of this study consisted of hotels listed in The American Hotel and Motel Association's Directory of Hotel and Motel Companies. A proportional stratified sample of ten hotel companies in 6 classifications was selected from the list and the hotel companjes were asked to provide their hotel housekeeping manuals, audits, or checklists. Fourteen responding hotels and 11 other selected hotels constituted the basis of this study. The classifications of the respondent hotels covered luxury, full service, midrange, limited service, casino/hotels, and budget properties.

A content analysis of hotel housekeeping operational audit procedures provided by the 25 hotels was performed to document the reported practices. The information from this analysis was compiled to form the hotel housekeeping operational "audit questionnaire". The questionnaire was field tested to further ensure the completeness and usability of the final operational audit questionnaire.

\section{Summary of Findings and Conciusions}

The findings of the study indicate that almost $80 \%$ of important hotel housekeeping department procedures and practices of reporting hotels were in 8 categories. Ranked in order of importance the categories were cleaning of guestrooms, public spacc cleaning, organization of deparment, inventory, human resources. preventive maintenance, laundry, and communications. The remaining $20 \%$, listed in order of importance, were in the categories of safety and security, guest services, training, expenses, and purchasing. 
It was indicated that guestroom and public space clearing were the most important areas in managing hotel housekeeping departments. The most emphasis was placed on guestroom cleaning procedures, particularly the living and bath areas followed by bed/mattress and entry. The most important areas in public space cleaning were corridors, hallways, elevators, vending, and lobbies. The remainder of the category delineated cleaning procedures for public restrooms, building exterior, back of the house, food and beverage outlets, and banquet facilities.

The next most important category reported was the organization of the department with the most emphasis placed on issues relating to the operations of the department. Managing and controlling inventories with an emphasis on par levels of guest room amenities and supplies were the most important procedures in the inventory category. In the human resources category issues regarding employee orientation, scheduling procedures and employec relations were the most important elements. Guestroom maintenance was the most important in the overall category of preventive maintenance. In the laundry category and communication category the most important procedures reported related to the needs of hotel guests.

The remaining $20 \%$ of the reported incidents were in the categories of safety/security, guest services. training, expenses, and purchasing.

An overview of the 13 major categories and sub-categories might reveal some anomalies such as the relative small number of incidents of guest services and food and beverage outlet cleaning in relation to the other categories. However, drilling down into the data shows that components of most sub-categories contain guest-related elements. 
One explanation of the anomaly of the number of reported incidents in food and beverage outlet cleaning could be the industry wide hotel norm that the food and beverage deparment is primarily responsible for cleaning their respective areas.

\section{Recommendations and Future Research}

Based on the results of this study, the following recommendations for implementing an operational audit are offered for consideration:

1) The operational audit could offer an important tool in various quality management programs. These programs usually present excellent foundations of quality management, but often need the specific tools to assess quality incidents.

2) Hoteliers could incorporate the operational audit as a management tool that might enhance existing methorls of maintaining operations in a more economic, efficient, and effective manner on an ongoing basis.

3) The audit could provide a systematic basis for delegating task responsibilities to all levels of employees.

4) An operational audit could provide employees and management with a means by which to gauge actual operating results compared to goals and objectives on a timely basis.

5) An independent operator could implement this generic audit as an individualized management tool that might not otherwise be available to their company.

6) Utilization of this audit could be for identifying the source of problems, not just the symptoms, and developing an altemative course of action on a timcly basis. 
7) Using the operational audit could be an important tool for employees in following up on items that need detailed and immediate attention.

8) Implementing an operational audit could provide a process for employees to be involved in the operation while simultaneously yielding valuable assistance to management.

9) Franchised or chain propesties already subject to audits or inspections could use this operational audit system to compare company audits to their own.

10) An operational audit could provide a basis for designing a measurable quality assurance program.

11) An operational audit could be incorporated into a quality management course as a practical tool to be utilized in hotel housekeeping deparments.

\section{Furure Research}

It is recommended for future research to replicate this study in other areas of hotel operations such as food and beverage, human resources, technology, engineering, and management. In terms of research design, it is recommended to utilize a focus group and an industry management survey to broaden the scope of data available for analysis. This data could be used to conduct a quantitative study on operational auditing that could yield results benefiting management in the hotel industry.

Another research project could refine the findings of this qualitative study. The major findings of this study could be used as a basis for a questionnaire design covering major 
hospitality management incidents which then would be rated by housekeeping managers and analyzed for importance and significance. 


\section{BIBLIOGRAPHY}

Ary, D., Jacobs, L.C. \& Razavieh, A. (1996). Introduction to research in education. NY: Holt, Rinehart \& Winston. Inc.

Berelson, B. (1952). Content analysis in communication rescarch. Glencoe, IL: Free Press.

Casado, M. A. (2000). Housekeeping management. NY: John Wiley \& Sons, Inc.

Corcell, Francis A., (1983). A checklist approach to operational auditing. The Practical Accountant. August.

Driessen, A. J. G., \& Molerkamp, A. (1993). The perspective of operational auditing: A new management tool. Managerial Auditing Journal. 19-23.

Flesher. D. L. \& Siewart, S. (1982). Independent auditor's guide to operational auditing. NY: John Wiley \& Sons, Inc.

Godick, N. B., (1979). Operational auditing: What it does and how it works. The Practical Accountant, 67-70.

Iverson, K. M. (1989). Introduction to hospitality management. NY: Van Nostrand Reinhold.

Kappa, M. M., Nitschke, A. \& Shappert, P.B. (1990). Managing housekeeping operations. East Lansing, MI: Educational Institute of the American Hotel \& Motel Association.

Kracauer. S. (1993). The challenge to qualitative content analysis. Public Oninion Quarterly, 16.631-642.

Kowalczyk, D. S. (1987). Cadmus' operational auditing. NY: John Wilcy \& Sons.

Lattin, W. G. (1989). The Lodging and Food Service Industry. MI: Educational Institute of American Hotel and Motel Association.

Mace, E. E. \& Valentine, R. C., (1984). Hope springs etemal. Management Focus. 2729.

Martin, R. J. (1998). Professional Management of Housekeening Operations. NY: John Wiley \& Sons, Inc. 
Meddaugh, E. J. (1979). How to perform an operational audit. The Practical Accountant.

Moreo, P. J., Savage, K. S., \& Sammons, G. (1997). Hotel front office operational audit: A questionnaire approach. The Bottomline, 12 (6), 16-20.

Moreo, P., Savage, K., (1990). Incorporation of operational audits in hotel front office courses. Hospitality Research Joumal. 14 (2), 243-254.

Morse, J. M. (1994). Emerging from the data: The cognitive processes of analysis in qualitative inquiry. In J.M. Morse (Ed.), Critical Issues in Qualitative Research Methods 23-43. Newbury Park, CA: Sagc.

Ponder, E. H. (1984). Operational auditing by CPA firms. The CPA Journal. 38-50.

Reider, H. R. (1994). The Complete Guide to Operational Auditing. NY: John Wiley \& Sons, Inc.

Reider, R. (1999). Operational Review: Maximum Results at Efficient Costs. NY: John Wiley \& Sons, Inc.

Schneider, M., Tucker, G. \& Scoviak, M. (1999). The Professional Housekeener. NY: John Wiley \& Sons, Inc.

Spraakman, G., Ibrahim, M. (1998). Cost-economizing superiority of operational audit findings to financial audit findings. Internal Auditing 13 (5), 34-43.

Thomhill, W. T. (1981). Complete Handbook of ()perational and Management Auditing. Englewood Cliffs, N.J.: Prentice-Hall, Inc. 


\section{APPENDIX A}

INSTITUTIONAL REVIEW BOARD APPROVAL 


\title{
Oklahoma State University Institutional Review Board
}

Protocol Expires: $\quad 5 / 23 / 02$

\author{
Date' Thursday, May 24, 2001 \\ IRB Application No HE0151
}

Proposal Tite: HOTEL HOUSEKEEPING OPERATIONAL AUDIT

Pnncipal

Investigator(s):

Donalo Wood

Painck J Moreo

210 HESW

210 HESW

Shillwater, OK 74078

Stillwater, OK 74078

Reviewed and

Processed as: Exempt

Approval Slatus Recommended by Reviewer(s), Approved

Dear $P$

Your IRB application referenced above has been approved for one calendar year. Please make note of the expiration date indicaled above. It is the judgment of the reviewers that the righls and welfare of individuals who may be asked to particlpate in this study will be respected, and that the research will be conducted in a manner consistent with the IRB requirements as outlined in section 45 CFR 46.

As Prncipal Investigator, it is your responsibility to do the following:

1 Conduat this study exactly as it has been approved. Any modificatioris to the research protocol must be submithed with the appropnale signatures for IRB approval.

2 Submit a request for continuation if the study extends beyond the aporoval period of one calendar year This continuation must receive IR8 review and approval before the research can continue

3 Report any adverse events to the IRB Chair promptly. Adverse events are those which are unanticipated and impacl the subjects during the course of this research; and

4 Notify the IRB office in writing when your research project is complete.

Please note that approved projects are subject 10 monitoring by the IRB. If you have questions about the IRB procedures or need any assistance from the Board, please contact Sharon Bacher, the Executive Secrelary to the IRB, in 203 Whitehurs: (phone: 405-744-5700, sbacher@okstate.edu).

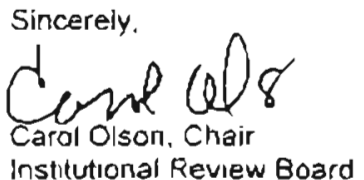




\section{VITA \\ Donald F. Wood \\ Candidate for the Degree of \\ Master of Science}

Thesis: HOTEL HOUSKEEPING OPERATIONAL AUDIT

Major Field: Hospitality Administration

Biographical:

Education: Graduated from Ellisville High School, Ellisville. Mississippi in May 1965; received Bachelor of Business Administration from The University of Mississippi, Oxford. Mississippi in August of 1971. Completed the requirements for the Master of Science degree with a major in Hotel and Restaurant Administration in August, 2001.

Professional Experience: Co-Founder, CEO of Wood Strauss Management Company, Inc., a diversified hospitality consulting and equity partner company, 1972 to present.

Professional Memberships: National Restaurant Association, CHRIE, Eta Sigma Delta. 